\title{
Targeting the histone demethylase LSD1 prevents cardiomyopathy in a mouse model of laminopathy
}

\author{
Anne-Claire Guénantin¹, Imen Jebeniani², Julia Leschik ${ }^{1}$ Erwan Watrin ${ }^{3}$, Gisèle Bonne ${ }^{4}$, Nicolas Vignier ${ }^{4}$, and Michel Pucéat ${ }^{1,2}$ \\ ${ }^{1}$ INSERM U-633, Paris Descartes University ${ }^{2}$ INSERM UMR-1251, MMG, Aix-Marseille University, Marseille, France. ${ }^{3}$ Centre National de la Recherche Scientifique, UMR6290, Rennes, France; Institut de \\ Cénétique et Développement de Rennes, Université de Rennes, Rennes, France. ${ }^{4}$ Sorbonne Université, INSERM UMRS974, Centre de Recherche en Myologie, Institut de Myologie, G.H. Pitié Salpêtrière, \\ F-75651 Paris Cedex 13, France.
}

\begin{abstract}
LMNA mutations in patients are responsible for a dilated cardiomyopathy. Molecular mechanisms underlying the origin and development of the pathology are unknown. Herein, using mouse pluripotent embryonic stem cells (ESCs) and a mouse model both harboring the p.H222P Lmna mutation, we found early defects in cardiac differentiation of mutated ESCs and dilatation of mutated embryonic hearts at E13.5, pointing to a developmental origin of the disease. Using mouse ESCs, we demonstrated that cardiac differentiation of $\mathrm{Lmna}^{\mathrm{H} 222 \mathrm{P} /+}$ was impaired at the mesodermal stage. Expression of Mesp1, a mesodermal cardiogenic gene involved in epithelial-to-mesenchymal transition of epiblast cells, as well as Snai1 and Twist expression, was decreased in Lmna ${ }^{\mathrm{H} 222 \mathrm{P} /+}$ cells compared with WT cells in the course of differentiation. In turn, cardiomyocyte differentiation was impaired. ChIP assay of H3K4me1 in differentiating cells revealed a specific decrease of this histone mark on regulatory regions of Mesp1 and Twist in Lmna ${ }^{\mathrm{H222P/+}}$ cells. Downregulation or inhibition of LSD1 that specifically demethylated H3K4me1 rescued the epigenetic landscape of mesodermal $L m n a^{\mathrm{H} 222 \mathrm{P} /+}$ cells and in turn contraction of cardiomyocytes. Inhibition of LSD1 in pregnant mice or neonatal mice prevented cardiomyopathy in E13.5 Lmna ${ }^{\mathrm{H} 222 \mathrm{P} / \mathrm{H} 222 \mathrm{P}}$ offspring and adults, respectively. Thus, LSD1 appeared to be a therapeutic target to prevent or cure dilated cardiomyopathy associated with a laminopathy.
\end{abstract}

\section{Introduction}

A-type lamins (i.e., lamin A/C) are ubiquitous proteins encoded by the LMNA gene via alternative splicing. Together with B-type lamins, they constitute the nuclear lamina essential for nuclear architecture. A-type lamins play essential functions in cell and organ physiology, including cell mechanotransduction, intracellular signal transduction, and chromatin organization through the lamina-associated domains (LADs) (1, 2), mostly but not exclusively (3) repressing gene transcription, DNA replication, and repair (4).

Mutations in LMNA are spread all over the gene and lead to multiple diseases, i.e. the laminopathies, including skeletal muscle dystrophies, cardiomyopathies, lipodystrophies, and premature aging. These mutations are mostly missense mutations that cause either haploinsufficiency and/or lead to nonfunctional proteins with potential toxicity $(5,6)$. We have learned for the last decade about the role of lamin $\mathrm{A} / \mathrm{C}$ as a scaffolding protein for the nucleoskeleton, mediator of signal transduction, and sensor of mechanotransduction (7). Its role as a direct or indirect chromatin modifier via the polycomb family of proteins (8-10) or any other histone marker writer or eraser is just emerging. However, how epigenetic defects would affect

Authorship note: ACG and IJ contributed equally to this work. GB and NV contributed equally to this work.

Conflict of interest: MP is the inventor of a pending patent on the use of LSD1 inhibitors for treatment of cardiac fibrosis (EP20305993).

Copyright: (c) 2021, American Society for Clinical Investigation.

Submitted: January 15, 2020; Accepted: September 16, 2020; Published: January 4, 2021.

Reference information: J Clin Invest. 2021;131(1):e136488.

https://doi.org/10.1172/JCl136488. pathophysiological embryonic development of individuals carrying mutated LMNA is still poorly understood. A role as a chromatin regulator would be cell type-specific because the human genome is mainly transcribed in a developmental stage- and cell type-specific manner (11). A recent article also suggested that LADs relocate according to cell type and differentiation stage (12). Misrelocalization of LADs and/or changes in histone modifications, and subsequently changes in gene transcription during embryonic development (13), may be at the origin of major components of laminopathies. This may further link a specific mutation to a specific phenotype in patients.

To address this question and in turn uncover potential therapeutic targets, we first used mouse embryonic stem cells (ESCs) harboring a p.H222P Lmna mutation, responsible for autosomal dominant Emery-Dreifuss muscular dystrophy, as a model for mechanistic studies. Indeed, embryonic pluripotent stem cells faithfully recapitulate early embryonic development including cardiogenesis (14). Although these cells express a low level of A-type lamins, expression increased during cell differentiation (15). The cells thus bring a valuable model to study laminassociated developmental defects. We also used p.H222P Lmna mouse embryos (16) bred in the sv129 genetic background (17) to revisit the putative embryonic cardiac phenotype.

We discovered that p.H222P Lmna mutation-associated cardiomyopathy originated at an early stage of embryonic development. An epigenetic event, i.e., erasement of the H3K4me1 mark on enhancers of genes whose expression is mandatory for the processes of epithelial-to-mesenchymal transition (EMT) and cardiogenesis, is responsible for the defect in cardiac development. Cardiac malformations leading to impaired ventricular function at the 
embryonic stage are responsible for the cardiomyopathy. An inhibitor of LSD1, the demethylase of H3K4me1, which was abnormally activated in $\mathrm{p} . \mathrm{H} 222 \mathrm{P}$ Lmna mutated cells, rescued both cardiogenesis and cardiac function. Thus, LSD1 constitutes a suitable therapeutic target to prevent laminopathy-associated cardiomyopathy.

\section{Results}

Lmna ${ }^{H 222 P / H 222 P}$ mutation is responsible for severe cardiac defects at an early embryonic stage. Lamin is expressed at early stages of embryonic development $(1,18)$. We thus surmised that an Lmna mutation may affect the formation of the heart, the first organ to be functional in the embryo.

In order to study the role of p.H222P mutation in early embryonic development, embryos were collected at E13.5. We investigated the cardiac structure of embryos carrying a $L m n a^{\mathrm{H} 222 \mathrm{P} / \mathrm{H} 222 \mathrm{P}}$ or $L m n a^{\mathrm{H} 222 \mathrm{P} /+}$ mutation or WT siblings. This analysis revealed that $40 \%$ of

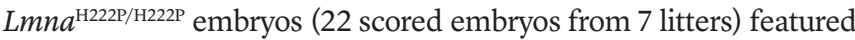
a dilated left ventricle compared with $8 \%$ of $L m n a^{\mathrm{H} 222 \mathrm{P} /+}$ (35 scored embryos from 9 litters) or WT siblings ( 24 scored embryos from 7 litters). Histological analysis of E13.5 embryonic heart sections stained with $\mathrm{H} \& \mathrm{E}$ and anti-sarcomeric $\alpha$-actinin labeling showed hypertrabeculation or noncompaction as well as an interventricular septum defect (yellow arrows) and enlarged atria (white arrow) in 85\% (45 scored embryos) of $L m n a^{\mathrm{H} 222 \mathrm{P} / \mathrm{H} 222 \mathrm{P}}$ hearts (Figure $1 \mathrm{~A}$ ).

The cardiac functionality of $L m n a^{\mathrm{H} 222 \mathrm{P} / \mathrm{H} 222 \mathrm{P}}, L_{m n} a^{\mathrm{H} 222 \mathrm{P} /+}$, and WT embryo siblings was monitored by in utero echography at E13.5. This analysis revealed that $40 \%$ of $L m n a^{\mathrm{H} 222 \mathrm{P} / \mathrm{H} 222 \mathrm{P}}$ embryos displayed very weak contractility (i.e., akinetic left ventricular wall) (Figure 1B) and $60 \%$ displayed significantly lower contractility; the ejection fraction of $L m n a^{\mathrm{H} 222 \mathrm{P} / \mathrm{H} 222 \mathrm{P}}$ embryonic hearts was decreased by 1.8 -fold compared with $L m n a^{\mathrm{H} 222 \mathrm{P} /+}$ and WT embryo siblings (Figure 1, B and C). Ultrasound imaging of the live fetus showed that $L m n a^{\mathrm{H} 222 \mathrm{P} / \mathrm{H} 222 \mathrm{P}}$ embryos displayed an increased left ventricular volume during both the systole and diastole (Figure 1D). The internal diameter of the chamber was significantly increased when measured by echocardiography (Figure 1E) or histology ( $2 \pm 0.1$ vs. $0.9 \pm 0.2 \mathrm{~mm}, n=15 /$ group, $P \leq 0.01$ ) (Figure 1A), whereas the left ventricular wall thickness was decreased (Figure $1 \mathrm{E}$ ) in $L m n a^{\mathrm{H} 222 \mathrm{P} / \mathrm{H} 222 \mathrm{P}}$ compared with Lmna ${ }^{\mathrm{H} 222 \mathrm{P} /+}$ or WT embryonic hearts. The thickness of the interventricular septum was not significantly different in $L m n a^{\mathrm{H} 222 \mathrm{P} / \mathrm{H} 222 \mathrm{P}}$ versus Lmna ${ }^{+/ \mathrm{H} 222 \mathrm{P}}$ or WT hearts (Figure 1E).

Collectively, these data demonstrated that $L m n a^{\mathrm{H} 222 \mathrm{P} / \mathrm{H} 222 \mathrm{P}}$ embryonic hearts already featured a dilated cardiomyopathy at E13.5. In line with the severe cardiomyopathy observed in $40 \%$ of

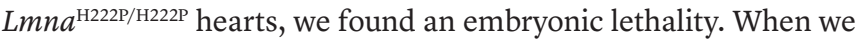
bred lmna ${ }^{\mathrm{H} 222 \mathrm{P} / \mathrm{H} 222 \mathrm{P}}$ with $1 \mathrm{mna}{ }^{\mathrm{H} 222 \mathrm{P} / \mathrm{H} 222 \mathrm{P}}$ mice, we obtained litters of only $3.5 \pm 0.5$ neonates $(n=5)$ instead of $9 \pm 1$ neonates in WT or heterozygous breeding setups $(n=6)$.

Transcriptional deregulation in embryonic Lmna ${ }^{H 222 P / H 222 P}$ hearts. In order to gain insight into the molecular mechanisms of embryonic cardiac defects in $L m n a^{\mathrm{H} 222 \mathrm{P} / \mathrm{H} 222 \mathrm{P}}$ mice, we carried out RNASeq of E13.5 heterozygous p.H222P/ ${ }^{+}$or homozygous p.H222P/ $\mathrm{H} 222 \mathrm{P}$ hearts. The analysis revealed 636 and 1111 upregulated and downregulated genes, respectively (fold change $\log _{2}=2$ ) in the homozygous $\mathrm{p} . \mathrm{H} 222 \mathrm{P} / \mathrm{H} 222 \mathrm{P}$ versus the heterozygous hearts (Supplemental Figure 1A). The volcano plot in Supplemental Figure $1 \mathrm{~A}$ highlights a few cardiac genes, including genes involved in
$\mathrm{Ca} 2^{+}$homeostasis, ventricular trabeculation, and the encoding of sarcomeric proteins or transcription factors in homozygous and heterozygous mouse hearts. The membrane (Cav) and sarcoplasmic reticulum $(R y R 2)$ calcium channels, as well as potassium channels Kcnq and phospholamban (PLN), were downregulated in homozygous hearts. Genes encoding sarcomeric proteins such as $M y l 2$ or $M y h 7$ were also less expressed in homozygous than heterozygous hearts. Isl1, a marker of progenitor cells, was instead upregulated. Genes involved in ventricular trabeculation (Notch, BMP1O) were also downregulated in homozygous p.H222P/ $\mathrm{H} 222 \mathrm{P}$ hearts versus heterozygous p.H222P/ ${ }^{+}$hearts. Real-time qPCR confirmed the downregulation of Notch1 and BMP1O and the upregulation of Has2 (Supplemental Figure 1B).

Mouse ESCs carrying Lmna ${ }^{\mathrm{H} 222 \mathrm{P} / \mathrm{+}}$ recapitulate cardiac differentiation defects. To better understand the mechanistic events underlying cardiac defects at early onset, we then tested the ability of the mouse WT and $L m n a^{\mathrm{H} 222 \mathrm{P} /+}$ ESCs to differentiate into cardiac mesoderm and cardiac myocytes. ESCs were differentiated within embryoid bodies (EBs) using the hanging drop method (19, 20). We observed that EBs derived from $L m n a^{\mathrm{H} 222 \mathrm{P} /+}$ cells were significantly smaller when compared with WT cells (data not shown). Gene expression monitored by real-time PCR revealed that Brachyury ( $T$ ), a gene transiently expressed in pan-mesoderm (day $5 \mathrm{EBs}$ ) was upregulated at days 5 and 7 of differentiation in Lmna ${ }^{\mathrm{H} 222 \mathrm{P} /+}$ compared with WT EBs. In contrast, Mesoderm posterior 1/2 (Mesp1/2), one of the earliest transcription factors marking the cardiac mesoderm, was downregulated in $L m n a^{\mathrm{H} 222 \mathrm{P} /+}$ compared with WT cells (Figure 2A). Genes expressed earlier or concomitantly with Mesp1 in the mesoderm Mix Paired-Like Homeobox (Mixl1), Goosecoid (Gsc), Eomesodermin (Eomes), and Fibroblast growth factor 8 (FGF8) were also downregulated in $L m n a^{\mathrm{H} 222 \mathrm{P} /+}$ compared with WT in day 3 and day 4 EBs (Supplemental Figure 2), suggesting a defect in mesendoderm and cardiogenic mesoderm determination of these cells. The pattern of expression of $M e f 2 c, N k x 2.5, T b x 5$, and Isl1 also pointed to a block in cardiac differentiation of $L m n a^{\mathrm{H} 222 \mathrm{P} /+}$ cells compared with WT EBs at day 7 (Figure 2A). Immunodetection of sarcomeric $\alpha$-actinin protein in Lmna $^{\mathrm{H} 222 \mathrm{P} /+}$ showed myofibrillar disarray in contrast to WT EBs at day 7, harboring a full organization of sarcomeres (Figure 2B). Altogether, these data demonstrated that $L m n a^{\mathrm{H} 222 \mathrm{P} /+}$ cells were not able to differentiate properly into cardiac cells.

We then investigated the functionality of $L_{m n a^{\mathrm{H} 222 \mathrm{P} /+}}$ cells during cardiac differentiation. Daily counting of beating EBs from day 7 to day 18 showed a reduced beating activity of EBs and a significant delay in cardiac differentiation: $L m n a^{\mathrm{H} 222 \mathrm{P} /+}$ cardiomyocytes started beating at day 14, whereas WT cardiomyocytes started beating at day 7 (Figure 2C). Recording of intracellular $\mathrm{Ca}^{2+}$ transients further showed $\mathrm{Ca}^{2+}$ spiking in WT but not in $\mathrm{Lmna}^{\mathrm{H} 222 \mathrm{P} /+} \mathrm{EBs}$ at day 10 of differentiation (Supplemental Figure 3). $L m n a^{\mathrm{H} 222 \mathrm{P} /+_{-}}$ mutated mouse ESCs recapitulated developmental cardiac defects that may account for dilated cardiomyopathy in mouse embryos.

Lmna ${ }^{H 222 P /+}$ mutation affects mesodermal differentiation through EMT defects. Next, we reasoned that Mesp1 regulates EMT of mesendodermal cells and allows the cells to migrate from the posterior to the anterior region of the embryo $(21,22)$. Expression of EMT genes, E-cadherin, Snail, and Twist, was monitored in the course of differentiation of WT and $L m n a^{\mathrm{H} 222 \mathrm{P} /+}$ mouse ESCs. E-cadherin 
A
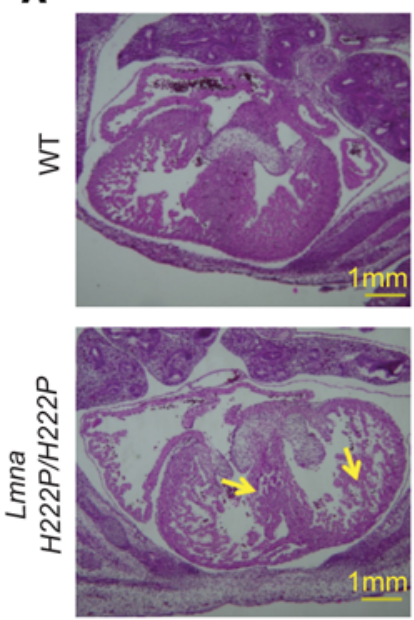

C

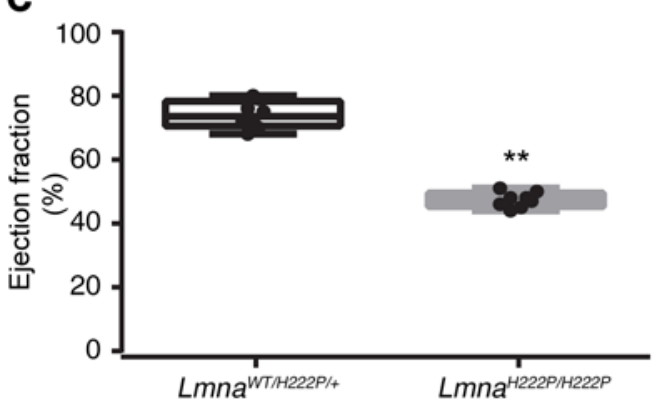

E

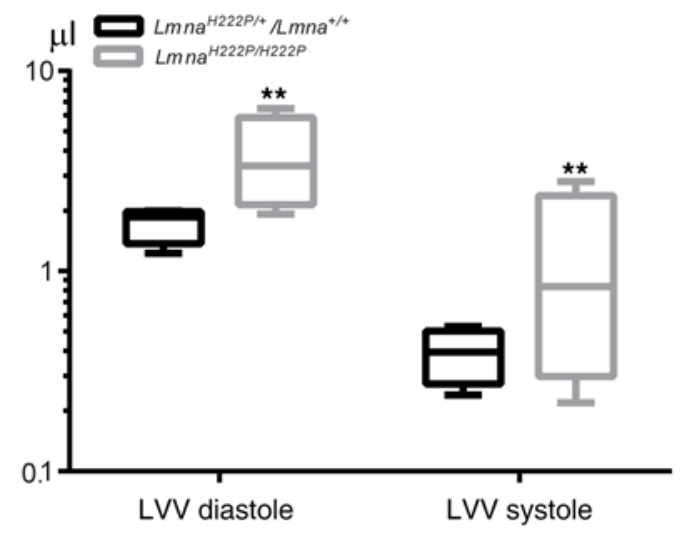

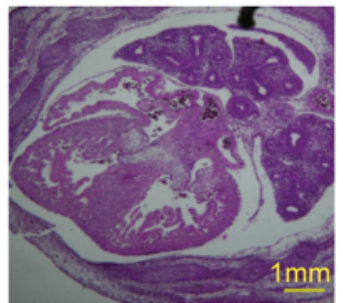
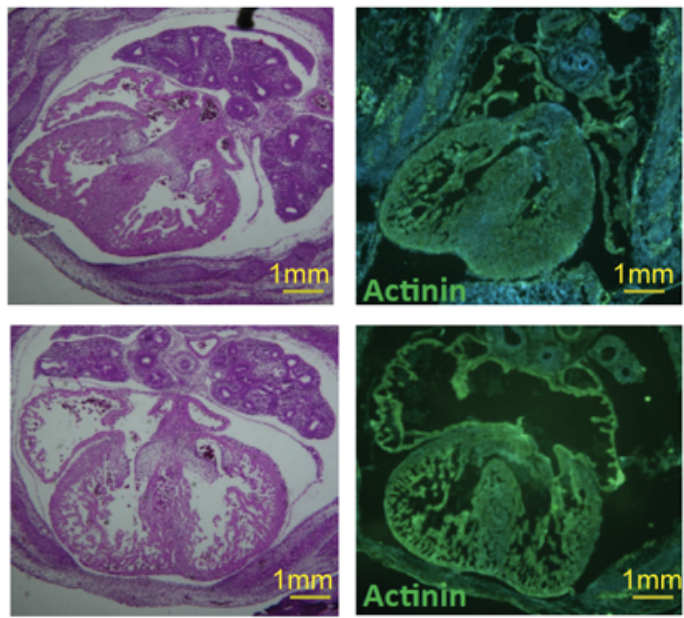

D

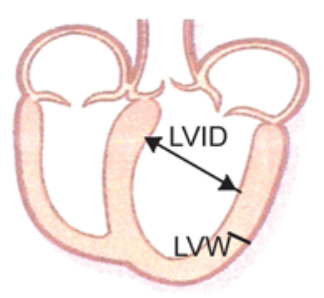

$\mathbf{F}$

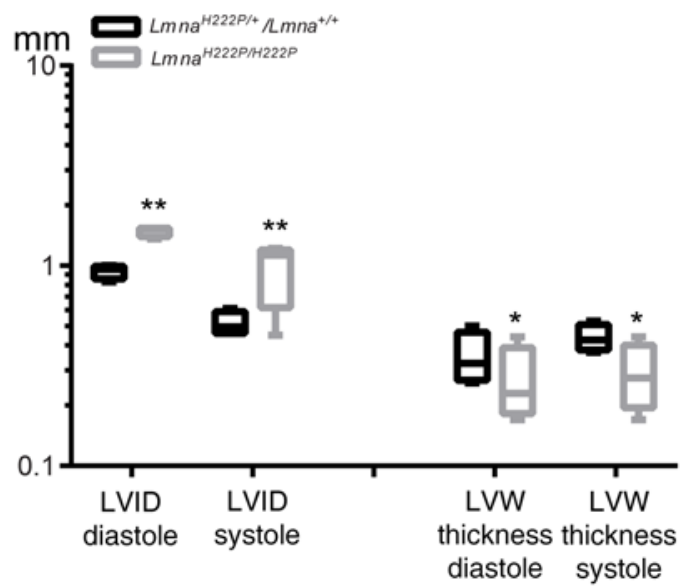

Figure 1. $\mathbf{L} \mathbf{m n a}^{\mathrm{H222P/H222P}}$ mutation leads to cardiac defects in vivo in mouse embryos. (A) H\&E staining and IHC with an antibody against $\alpha$-sarcomeric actinin (right panel) of WT and Lmna ${ }^{\mathrm{H} 222 \mathrm{P} / \mathrm{H} 222 \mathrm{P}}$ embryonic hearts at E13.5. Bars show the thickness of the left ventricular wall. Yellow arrows point to the trabeculations of the ventricles in a $L m n a^{\mathrm{H} 222 \mathrm{P} / \mathrm{H} 222 \mathrm{P}}$ heart. The white arrow points to the enlarged atrium. (B) Echocardiographic analysis of E13.5 WT or $L m n a^{\mathrm{H} 222 \mathrm{P} /+}$ and $L m n a^{\mathrm{H} 222 \mathrm{P} / \mathrm{H} 222 \mathrm{P}}$ embryonic hearts. (C) Ejection fraction of left ventricle of $L m n a^{\mathrm{H} 222 \mathrm{P} /+}$ and $L m n a^{\mathrm{H} 222 \mathrm{P} / \mathrm{H} 222 \mathrm{P}}$ embryonic hearts. (D) Inset: heart drawing showing measured parameters. (E) Left ventricular volume during diastole or systole and (F) left ventricular internal diameter during diastole or systole and intraventricular septum diameter. Data are represented as mean of 9 hearts \pm SEM. One-tailed Student's $t$ test; ${ }^{*} P<0.05$, ${ }^{*} P<0.01$. Hearts with very poor contractility were not included in echocardiography analysis.

was upregulated at day 4 of differentiation in $L m n a^{\mathrm{H} 222 \mathrm{P} /+}$ cells compared with WT cells (Figure 3A). This was further confirmed by a significantly higher enrichment of $\mathrm{H} 3 \mathrm{~K} 4 \mathrm{me} 1$ and $\mathrm{H} 3 \mathrm{~K} 27 \mathrm{ac}$ on 2 enhancers upstream of the promoter of $E$-cadherin of $L m n a^{\mathrm{H} 222 \mathrm{P} /+}$ versus WT EBs at day 4 of differentiation (Supplemental Figure 4). In contrast, Twist, an early player in the EMT process, and Snail were first induced in EBs at day 4 of differentiation in WT and mutated cells. Expression of both genes still increased at differentiation days 5 and 6 in WT EBs, but reached a plateau in Lmna ${ }^{\mathrm{H} 222 \mathrm{P} / \mathrm{+}}$-mutated EBs (Figure 3A). It should be noted that LSD1 expression was increased in $L m n a^{\mathrm{H} 222 \mathrm{P} /+}$ EBs compared with WT at day 4 of differentiation (Supplemental Figure 5). 
A
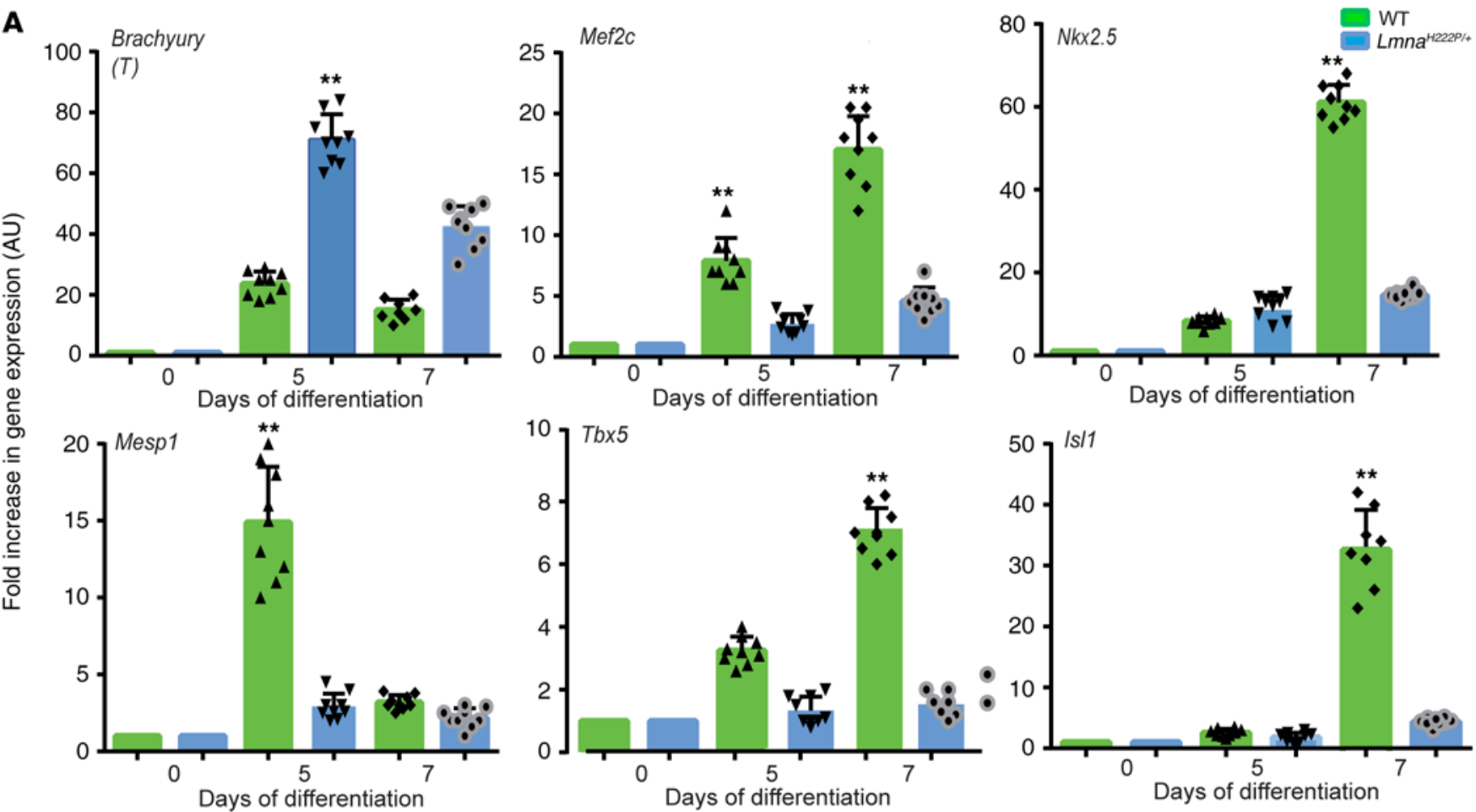

B
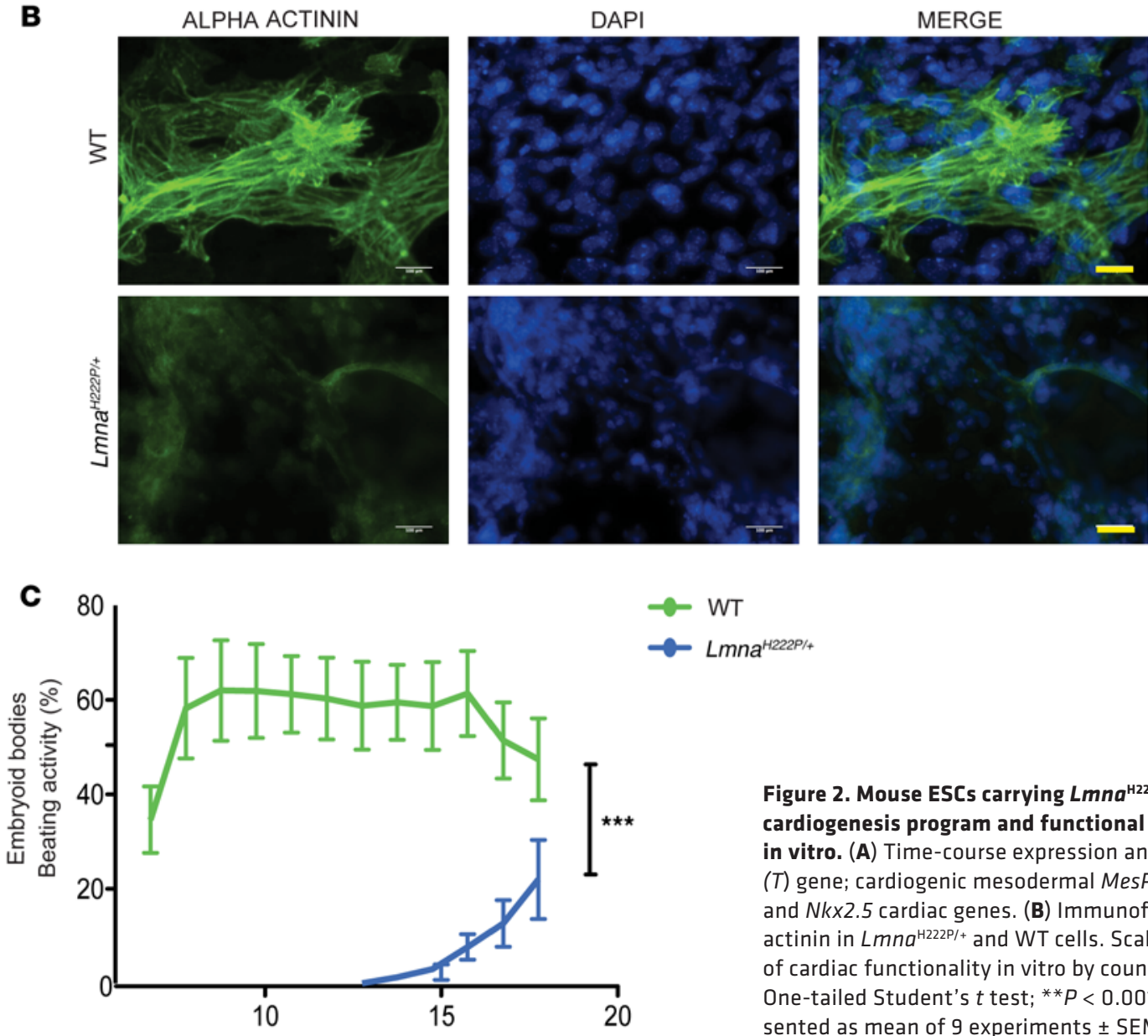

Figure 2. Mouse ESCs carrying Lmna ${ }^{\mathrm{H} 222 \mathrm{P} /+}$ mutation show delayed cardiogenesis program and functional defects during differentiation in vitro. (A) Time-course expression analysis of mesodermal Brachyury (T) gene; cardiogenic mesodermal MesP1 gene; and Mef2c, Tbx5, Is I1, and $N k \times 2.5$ cardiac genes. (B) Immunofluorescence against $\alpha$-sarcomeric actinin in Lmna ${ }^{\mathrm{H} 222 \mathrm{P} /+}$ and WT cells. Scale bars: $100 \mu \mathrm{m}$. (C) Assessment of cardiac functionality in vitro by counting the number of beating EBs. One-tailed Student's $t$ test; ${ }^{* *} P<0.001,{ }^{* *} P<0.005$; data are represented as mean of 9 experiments \pm SEM 

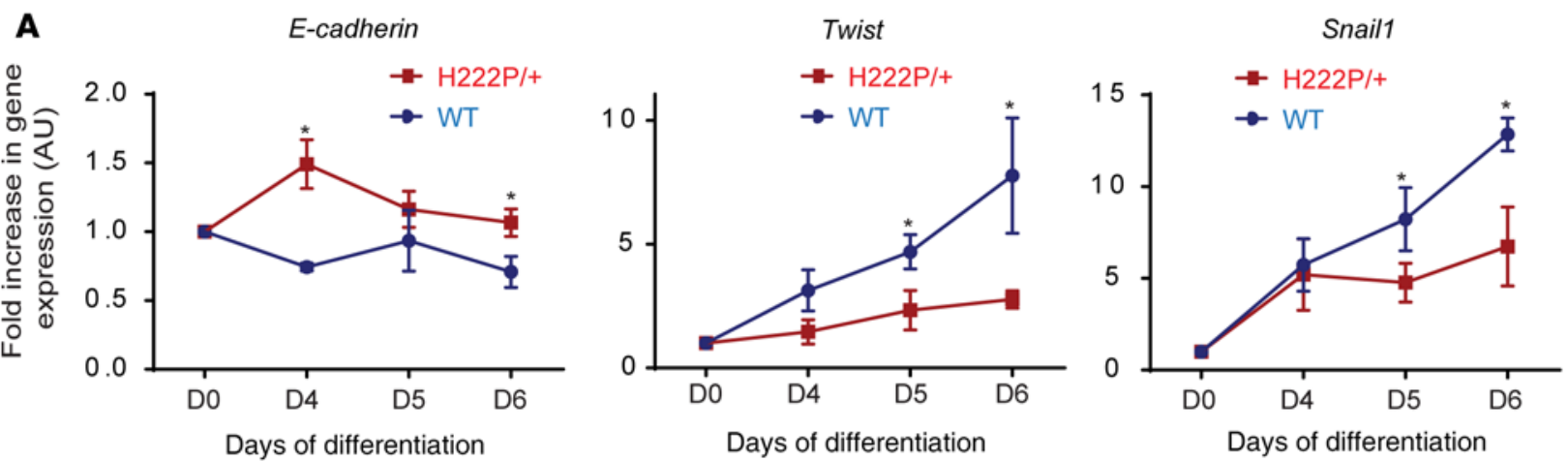

B
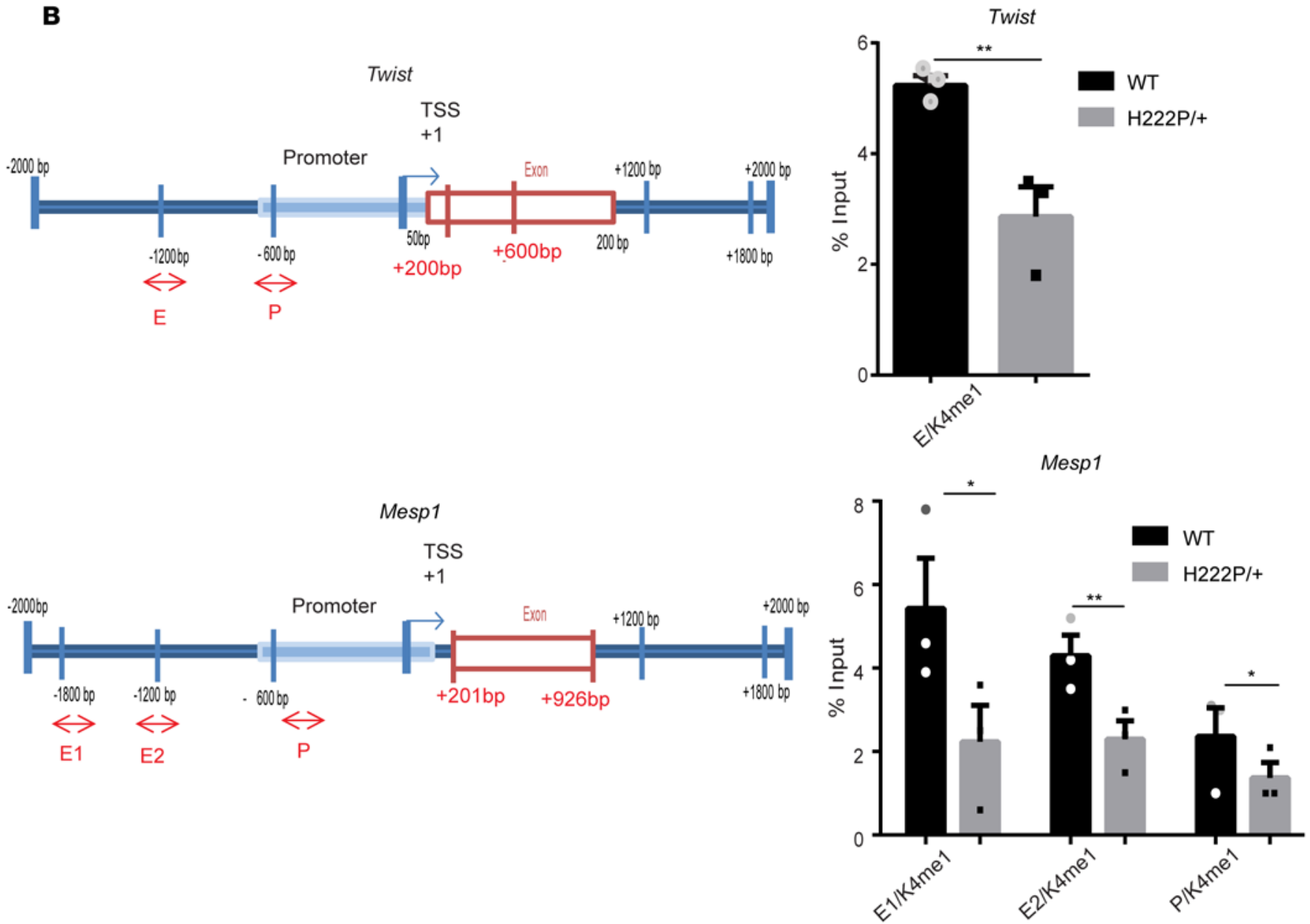

Figure 3. Lmna ${ }^{\mathrm{H} 222 \mathrm{P} /+}$ mutation affects mesodermal differentiation through EMT defects. (A) Expression of $E$-cadherin, Twist, and Snail/ genes in differentiating EBs. (B) ChIP-qPCR assay using an anti-H3K4me1 antibody. Both Twist and Mesp1 regulatory regions (left panels) were interrogated. Results are expressed as a percentage of input (right panels) of 3 separate experiments. One-tailed Student's $t$ test; ${ }^{*} P<0.05,{ }^{* *} P<0.01$.

A-type lamins are associated with chromatin and are likely to regulate chromatin modifiers. EMT is a process accompanied by chromatin remodeling dependent upon the demethylase LSD1, which modulates the methylation status of H3K4me1, an epigenetic mark associated with activated enhancers/promoters (23). Using ChIP assay, we thus interrogated the specific epigenetic mark H3K4me1 that occupied the regulatory regions of Twist and Mesp1 in chromatin extracted from WT or Lmna ${ }^{\mathrm{H} 222 \mathrm{P} / \mathrm{+}}$ EBs at day 4 (Figure
3B). The left panel shows the genomic regulatory regions investigated on both Twist and Mesp1 loci. H3K4me1 occupied the 3' and $5^{\prime}$ regulatory regions of both genes (data not shown). However, less mark was deposited on regulatory region (enhancer) E of Twist and on regions E (enhancer) 1, E2, and P (promoter) of Mesp1 on DNA extracted from chromatin of $L m n a^{\mathrm{H} 222 \mathrm{P} /+}$-mutated EBs compared with chromatin from WT EBs (Figure 3B, right panel). We interrogated the H3K9me2 epigenetic mark that is also modulated by LSD1 
A
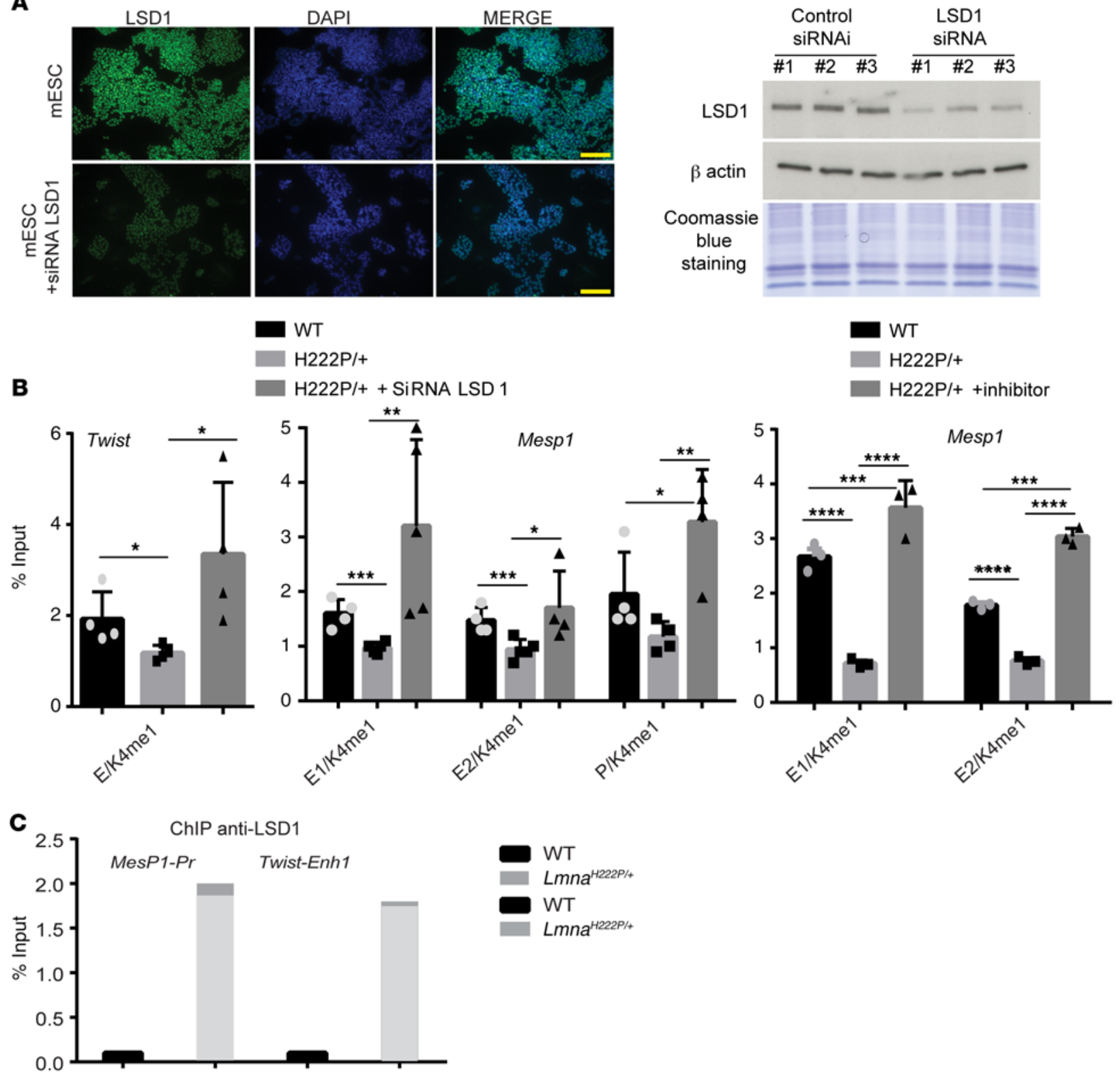

Figure 4. LSD1 downregulation rescues epigenetic, transcriptional, and functional defects in Lmna ${ }^{\mathrm{H} 222 \mathrm{P} /+}$ EBs. (A) LSD1 was downregulated in ESCs by transfection of a siRNA. LSD1 expression was monitored by immunostaining (left panel) or Western blot (right panel) with an anti-LSD1 antibody. (B) ChIP-qPCR assay using an anti-H3K4me1 antibody. Both Twist and Mesp1 regulatory regions were interrogated using chromatin extracted from WT or Lmna ${ }^{\mathrm{H} 222 \mathrm{P} /+}$ EBs generated from LSD-siRNA transfected ESCs. Results are expressed as a percentage of input from 3 separate experiments. Multiple 1-tailed Student's $t$ tests corrected for multiple comparisons using the Holm-Šídák method were used to compare each experimental condition. (C) ChIP-qPCR assay using an anti-LSD1 antibody. Both Twist and Mesp1 regulatory regions were interrogated using chromatin extracted from WT or $\mathrm{Lmna}^{\mathrm{H} 222 \mathrm{P} /+} \mathrm{EBs}$. The experiment was repeated twice with similar results (light versus dark gray bar).

(24) on both Twist and Mesp1 promoters. We did not find any significant differences in the enrichment of H3K9me2 of both genes' promoters between WT and Lmna ${ }^{\mathrm{H} 222 \mathrm{P} /+}$ EBs (Supplemental Figure 6).

Inhibition of LSD1 corrects epigenetic and genetic defects of Lmna ${ }^{\mathrm{H} 222 \mathrm{P} /+}$ ESC differentiation in vitro. The data obtained from ChIP experiments suggested that LSD1 was more active at specific loci in $L m n a^{\mathrm{H} 222 \mathrm{P} /}$-mutated cells than in WT cells, thus erasing the H3K4me1 epigenetic mark. Such activity could not be explained by the enzymatic activity of LSD1, which was found unchanged in WT and $L m n a^{\mathrm{H} 222 \mathrm{P} / \mathrm{+}}$ EBs or mouse embryonic hearts (data not shown).
Experiments were thus designed to inhibit LSD1 using both a siRNA approach and a selective pharmacological inhibitor, GSK-LSD1.

We first showed that transfection of ESCs prior to differentiation with the LSD1 siRNA was efficient at downregulating demethylase (Figure 4A). Next, ChIP experiments were used to interrogate the H3K4me1 epigenetic mark sitting on the Twist and MesP1 regulatory regions. Downregulation of LSD1 in ESCs allowed for a restoration of H3K4me1 on both genes, surrounded by chromatin extracted from $L m n a^{\mathrm{H} 222 \mathrm{P} /+}$ EBs when compared with WT EBs, both collected at day 4 (Figure 4B). The enrichment 
in $\mathrm{H} 3 \mathrm{~K} 4 \mathrm{me} 1$ on Twist and MesP1 regulatory regions in $L m n a^{\mathrm{H} 222 \mathrm{P} /+}$ EBs derived from LSD1-downregulated ESCs was lower than in chromatin extracted from WT EBs. ChIP anti-LSD1 of chromatin extracted from EBs at day 4 revealed a much stronger enrichment of demethylase on the Twist promoter and Mesp1 enhancer in Lmna ${ }^{\mathrm{H} 222 \mathrm{P} /{ }^{+}}$-mutated EBs versus WT EBs (Figure 4C).

Inhibition of LSD1 corrects impaired cardiac Lmna ${ }^{\mathrm{H} 222 \mathrm{P} /+}$ ESC differentiation and function in vitro. Inhibition of LSD1 activity relieved the block of cardiac differentiation, as shown by $M l c 2 a$ and $M l c 2 v$ expression in $L m n a^{/ \mathrm{H} 222 \mathrm{P} /+}$-mutated EBs (Figure $5 \mathrm{~A}$ ). The expression level of these genes in $L m n a^{\mathrm{H} 222 \mathrm{P} /+}$ ESCs reached the expression level in WT ESCs (Figure 5A). Of note, blunting LSD1 expression in ESCs prior to differentiation of WT cells did not significantly affect the $M l c 2 a$ or $M l c 2 v$ expression level (data not shown). Treatment of $L m n a^{\mathrm{H} 222 \mathrm{P} /+}$ EBs with GSK-LSD1, a pharmacological inhibitor of LSD1, rescued cardiac differentiation as indexed by sarcomeric $\alpha$-actinin immunostaining, which revealed well-organized sarcomeric structures (Figure 5B). Beating activity of WT EBs and $L m n a^{\mathrm{H} 222 \mathrm{P} /+}$ EBs treated or not with the GSK-LSD1 inhibitor applied at days 0-5 further indicated that the inhibitor rescued the beating activity of $L m n a^{\mathrm{H} 222 \mathrm{P} /+} \mathrm{EBs}$. Lmna ${ }^{\mathrm{H} 222 \mathrm{P} /+}$ EBs treated by the inhibitor started to beat much earlier than nontreated EBs, and the percentage of beating EBs almost reached the percentage observed with WT EBs. Interestingly, the beating of WT EBs treated with GSK-LSD1 inhibitor was improved compared with WT nontreated EBs (Figure 5C).

GSK-LSD1 treatment of Lmna ${ }^{\mathrm{H} 222 \mathrm{P} / \mathrm{H} 222 \mathrm{P}}$ mice prevents cardiomyopathy. GSK-LSD1 treatment of Lmna ${ }^{\mathrm{H} 222 \mathrm{P} / \mathrm{+}}$ EBs rescued the cardiac phenotype. Thus, we designed experiments to test the potential preventive therapeutic strategy on $L m n a^{\mathrm{H} 222 \mathrm{P} / \mathrm{H} 222 \mathrm{P}}$ mice. Pregnant females were treated with $1 \mathrm{mg} / \mathrm{kg}$ of GSK-LSD1 at E7.5 and E8.5. In utero E13.5 embryonic hearts were then collected for histological analysis.

This set of experiments revealed that GSK-LSD1 administered to the mother prevented the development of dilatation of the hearts of $L m n a^{\mathrm{H} 222 \mathrm{P} / \mathrm{H} 222 \mathrm{P}} \mathrm{E} 13.5$ embryos in the 5 litters tested, including 2 litters from parents that were both homozygous for the mutation (24 total Lmna ${ }^{\mathrm{H} 222 \mathrm{P} / \mathrm{H} 222 \mathrm{P}}$ embryos). H\&E staining of embryonic hearts also no longer indicated any cardiac defects in $L m n a^{\mathrm{H} 222 \mathrm{P} / \mathrm{H} 222 \mathrm{P}}$ embryos. No dilation of any of the chambers was observed, in contrast to $L m n a^{\mathrm{H} 222 \mathrm{P} / \mathrm{H} 222 \mathrm{P}}$ E13.5 embryos from the nontreated mothers (Figure $6 \mathrm{~A})$. Histopathology examination of the heart sections revealed that left ventricular diameter was not increased in $L m n a^{\mathrm{H} 222 \mathrm{P} / \mathrm{H} 222 \mathrm{P}}$ embryos from treated mothers compared with $L m n a^{\mathrm{H} 222 \mathrm{P} / \mathrm{H} 222 \mathrm{P}} \mathrm{E} 13.5$ embryos from nontreated mothers (Figure 6B). The left ventricle wall thickness in $L m n a^{\mathrm{H} 222 \mathrm{P} / \mathrm{H} 222 \mathrm{P}}$ embryos conformed to what is observed in WT embryos at this stage of development (25) or (Figure 1) in treated embryos, whereas it was significantly decreased in nontreated embryos (Figure 6C). The left ventricular function of embryonic hearts significantly affected in Lmna ${ }^{\mathrm{H} 222 \mathrm{P} / \mathrm{H} 222 \mathrm{P}}$ embryos from nontreated mothers was significantly increased in $70 \%$ of embryos from GSK-LSD1-treated mothers (Figure 6D).

We next reasoned that treatment of a pregnant mother would not be a realistic therapeutic approach. Furthermore, we thought that as a modulator of EMT, LSD1 could be a druggable target to limit cardiac fibrosis, a process developing at least in part from EMT of endothelial and more specifically epicardial and endocardial cells $(26,27)$. Data from the laboratory showed that GSK-LSD1 treatment of mice 1 week after myocardial infarction limited fibrosis and preserved left ventricular function (data not shown). We reasoned that birth, which increases cardiac demand, could trigger cardiomyocyte death and fibrosis in $L m n a^{\mathrm{H} 222 \mathrm{P} / \mathrm{H} 222 \mathrm{P}}$ mice. Because EMT-driven fibrosis starts by a loss in E-cadherin in endothelial cells, we first investigated the enrichment in H3K4me1 and H3K9 me 2 of $E$-cadherin regulatory regions in 1-week-old $L m n a^{\mathrm{H} 222 \mathrm{P} /+}$ and Lmna ${ }^{\mathrm{H} 222 \mathrm{P} / \mathrm{H} 222 \mathrm{P}}$ mouse hearts. These ChIP experiments revealed a significant decrease in both epigenetic marks sitting on the E-cadherin regulatory regions of $L m n a^{\mathrm{H} 222 \mathrm{P} / \mathrm{H} 222 \mathrm{P}}$ mouse hearts compared with $L m n a^{\mathrm{H} 222 \mathrm{P} /+}$ hearts (Supplemental Figure 7).

We thus treated $L m n a^{\mathrm{H} 222 \mathrm{P} / \mathrm{H} 222 \mathrm{P}}$ mice at birth at $\mathrm{P} 1$ and $\mathrm{P} 3$ when cardiomyocytes still proliferate (28) and when the cardiac demand of the neonate significantly increases, a phenomenon accelerating the death of myocytes and fibrosis. We then monitored cardiac fibrosis and cardiac function in 6-month-old male $L m n a^{\mathrm{H} 222 \mathrm{P} / \mathrm{H} 222 \mathrm{P}}$ mice. Mice treated at birth featured limited fibrosis and a normal heart shape with normal chamber sizes. In contrast, nontreated mice had left ventricular fibrosis and dilation (Figure 7A). The extent of fibrosis reached $32 \% \pm 5 \%$ in nontreated mice and $6 \%$ $\pm 3 \%$ in treated ones. Both the left ventricle and the atrium were dilated in nontreated mice, as previously observed (16). Cardiac function monitored by echocardiography revealed that nontreated mice developed severe heart failure with low ejection fraction. Five out of 6 mice died at 7 months old. Cardiac ventricular function of treated mice was significantly improved compared with nontreated mice (Figure 7B). None of the 8 treated mice died at 7 months old.

\section{Discussion}

Laminopathies that affect cardiac and skeletal muscle represent more than $79 \%$ of mutations identified so far in the LMNA gene. LMNA is one of the most frequent genes involved in dilated cardiomyopathies, which have an early onset for some patients with severe cases, ultimately requiring heart transplantation (29). Among LMNA mutations, p.H222P is a missense mutation that gives rise to autosomal dominant Emery-Dreifuss muscular dystrophy. Muscular dystrophy and a dilated cardiomyopathy affect patients carrying the LMNA p.H222P mutation (30). Patients carrying the LMNA p.H222P mutation suffer from muscular dystrophy and a dilated cardiomyopathy (30). How such a specific mutation on a ubiquitously expressed protein could feature such a specific muscle phenotype is still unknown.

Herein, we found that p.H222P mutation of A-type lamins, closely associated with chromatin, impaired a key epigenetic mechanism that underlies its effect as early as during the formation of the embryonic heart. We found that $L m n a^{\mathrm{H} 222 \mathrm{P} /+} \mathrm{ESCs}$ had an early block in cardiac cell differentiation. This observation led us to revisit the cardiac phenotype of $L m n a^{\mathrm{H} 222 \mathrm{P} / \mathrm{H} 222 \mathrm{P}}$ embryos. Interestingly, we found that as early as E13.5, these embryos had a dilated cardiomyopathy as found in the adult mice (16). This cardiomyopathy likely originates from a limitation in cardiac progenitors; a defect in trabeculation; and/or compaction of the ventricles, a severe cardiac defect. Indeed, RNA-Seq and real-time qPCR of embryonic hearts revealed a downregulation of Notch1 and BMP1O, a pathway that specifically regulates cardiomyocyte proliferation within the trabeculae (31). Notch1 has also been reported as being repressed by LSD1 $(32,33)$. A higher LSD1 activity within the Notch1 regulatory genomic region 
A

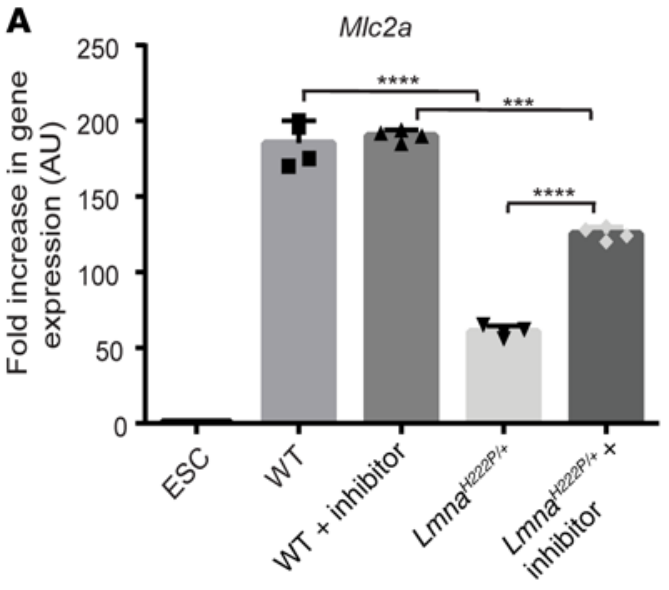

B
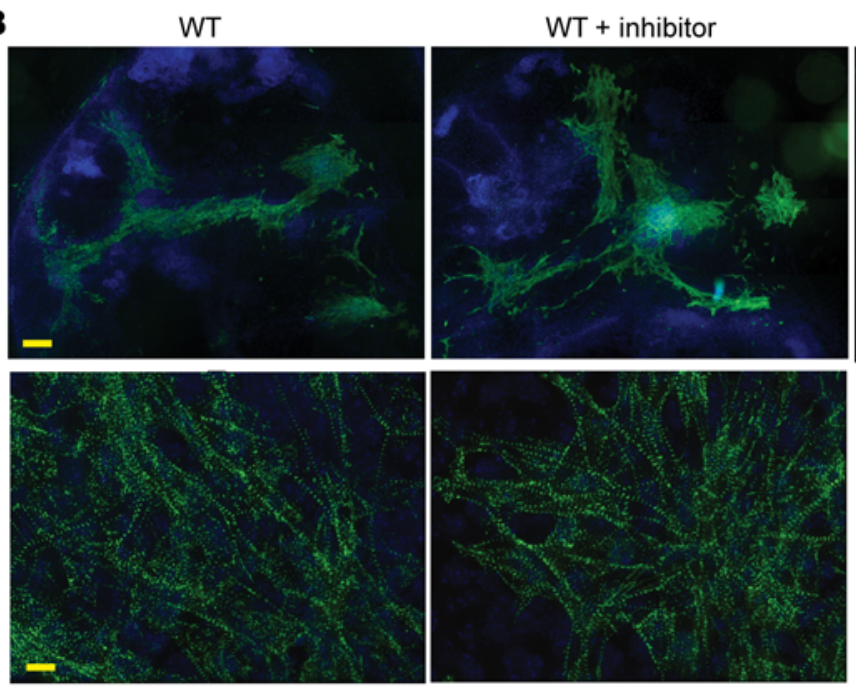

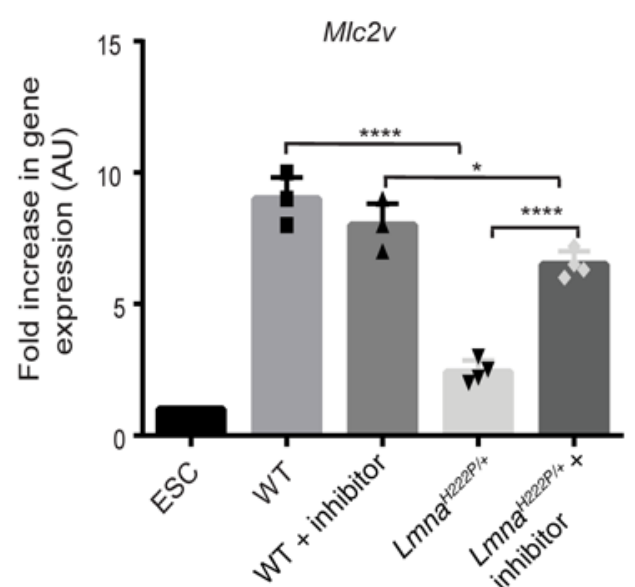

Lmna $\mathrm{H}^{\mathrm{H} 222 \mathrm{P} /+}$
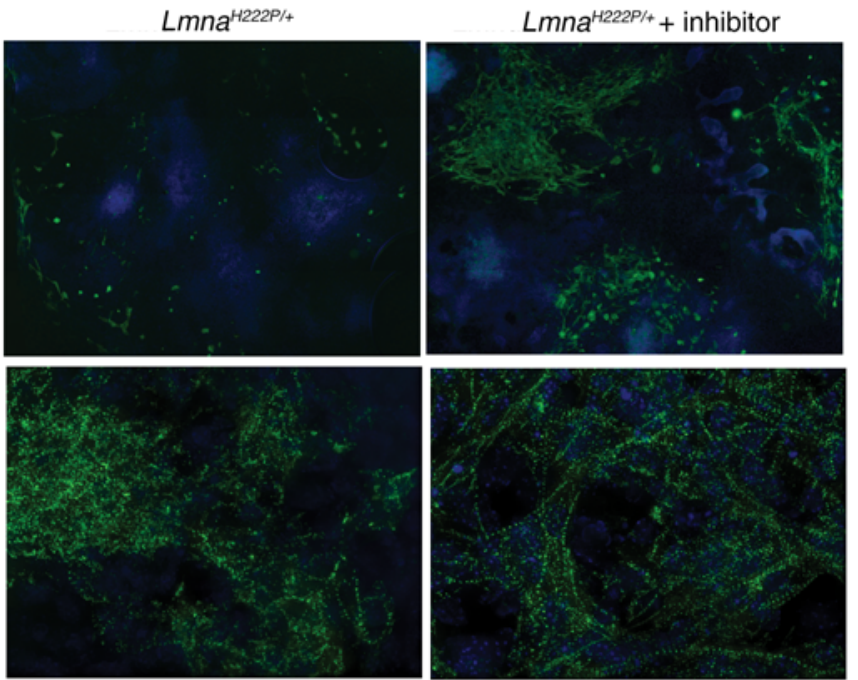

C

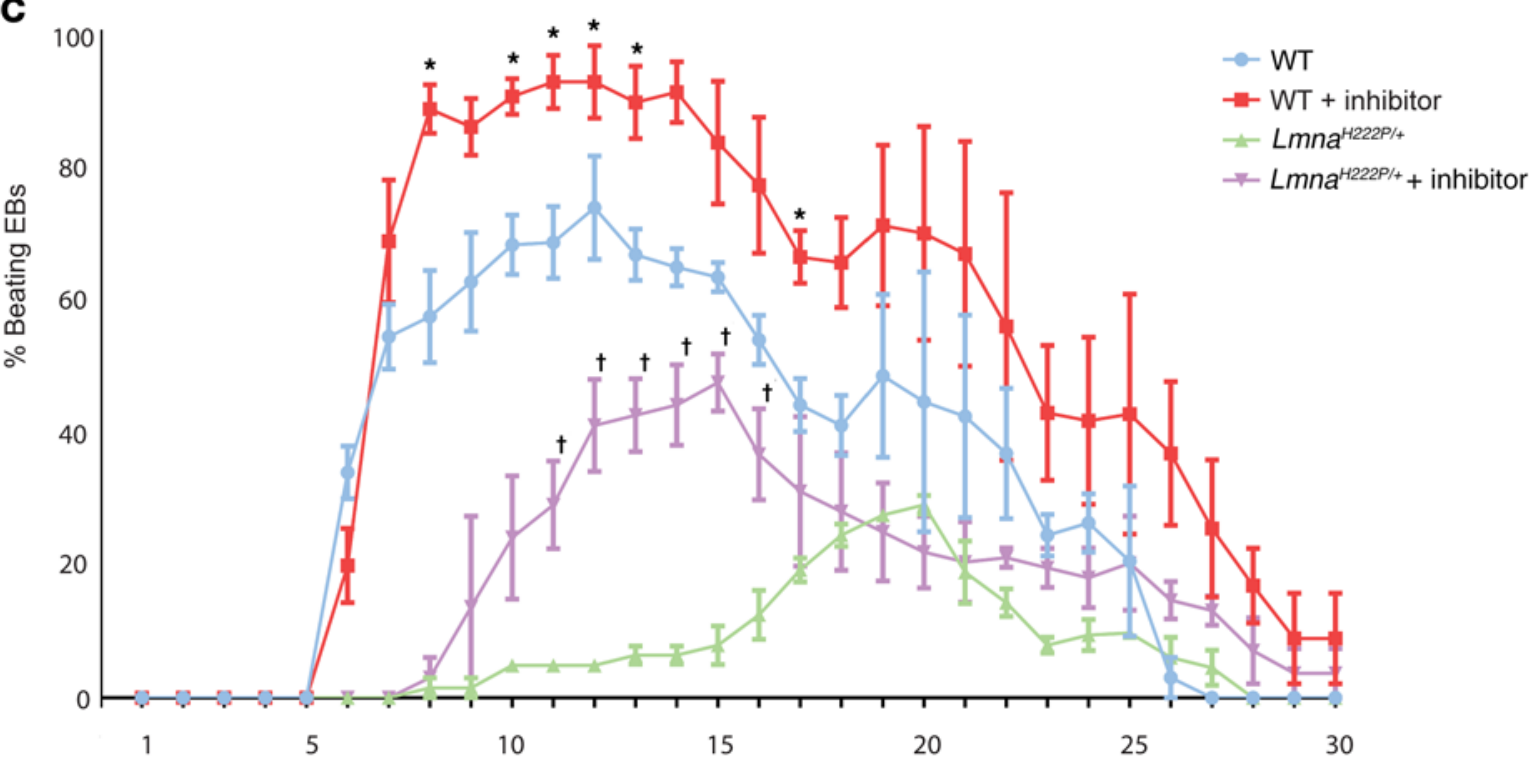

Figure 5. GSK-LSD1, the LSD1 inhibitor, rescues cardiogenesis of $\mathbf{L} \mathbf{m n a} \mathbf{a}^{\mathbf{H 2 2 2 P} /+} \mathbf{E S C s}$. (A) Real-time PCR of Mlc2a and Mlc2v genes in differentiating EBs at day 12 in WT and (B) anti-sarcomeric $\alpha$-actinin staining of Lmna ${ }^{\mathrm{H} 222 \mathrm{P} /+}$ EBs treated or not with GSK-LSD1; low (top) and high (bottom) magnification images. Multiple $t$ tests corrected for multiple comparisons using the Holm-Šidák method were used to compare each experimental condition ${ }^{*} P<0.05{ }^{*} P<$ $0.01 ;{ }^{* *} P<0.005 ;{ }^{* * *} P<0.001$. Scale bar: $50 \mu \mathrm{m}$. (C) Beating index of EBs WT or Lmna+H222P/+ treated or not with GSK1-LSD1 (inhibitor). The ${ }^{*}$ denotes comparison of day 10 WT EBs with WT EBs + inhibitor; the $†$ denotes comparison of $L m n a^{\mathrm{H} 222 \mathrm{P} /+}$ EBs treated or not with GSK-LSD1. Data are represented as mean of at least 4 experiments \pm SEM; 1-tailed $t$ tests; ${ }^{*} P<0.05$, ${ }^{* *} P<0.005$, ${ }^{* * * *} P<0.001$. 
A
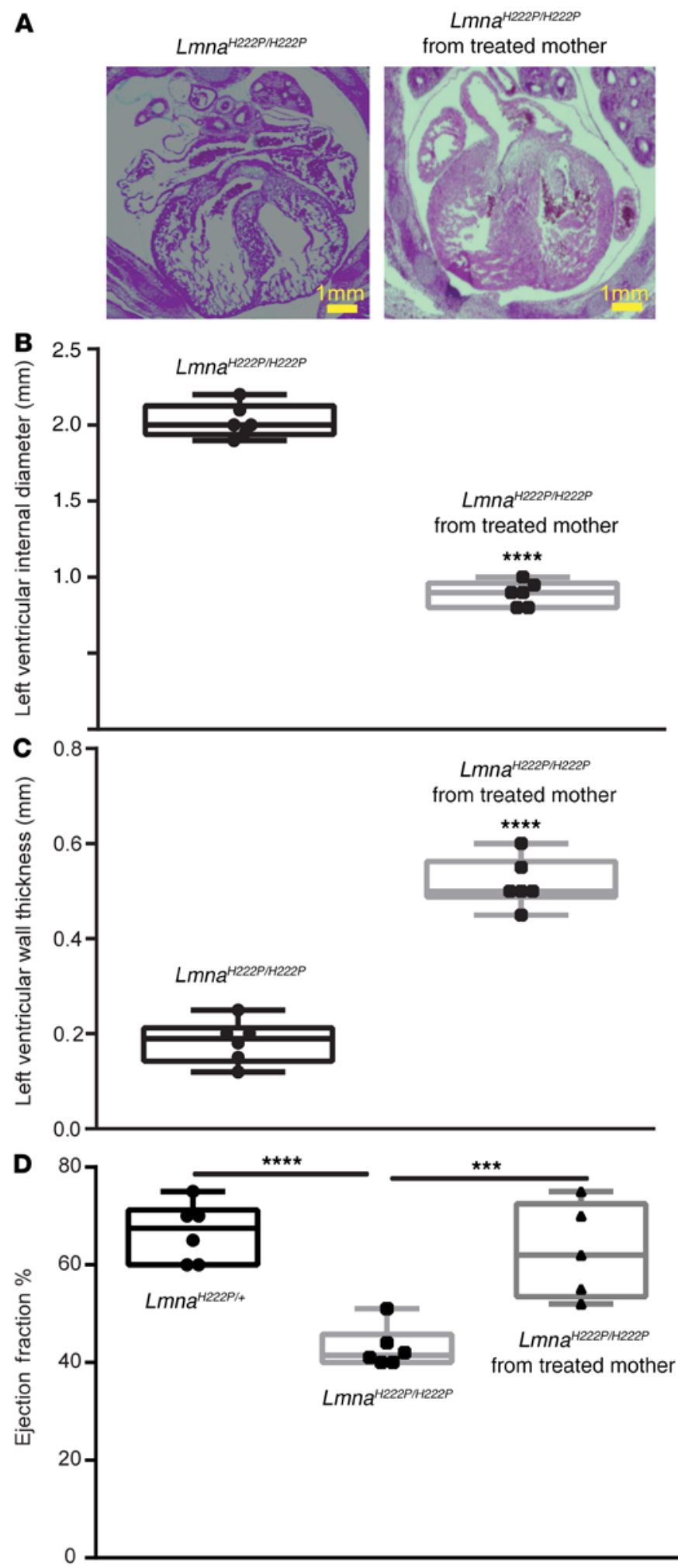

in the Lmna ${ }^{\mathrm{H} 222 \mathrm{P} / \mathrm{H} 222 \mathrm{P}}$ embryonic heart may account for the downregulation of the gene and limitation of the number of cardiomyocytes within the trabeculae. This would add to the limitation of cardiac progenitors earlier at the mesodermal stage of development and lead to thin ventricular walls at the origin of the cardiomyopathy.

Interestingly, laminopathyaffectsveryyoungpatients $(34,35)$. Our data, together with clinical observations, thus point to the congenital
Figure 6. CSK-LSD1, the LSD1 inhibitor, rescues cardiogenesis of Lmna ${ }^{\text {H222P/H222P }}$ embryos. (A) Histopathology consisted of H\&E staining and analysis of E13.5 Lmna ${ }^{\mathrm{H} 222 \mathrm{P} / \mathrm{H} 222 \mathrm{P}}$ embryonic hearts from embryos of pregnant females treated or not with the GSK-LSD1 inhibitor at E7.5 and E8.5. (B) Left ventricle diameter and (C) left ventricle wall thickness. The experimental conditions and measurements used in $\mathbf{B}$ and $\mathbf{C}$ were the same as in Figure 1. ( $n=6$ embryos from 3 different litters). ${ }^{* * *}$ Significantly different 1-tailed Student's $t$ test, $P<0.001$. (D) Echocardiographic monitoring of ventricular ejection fraction. The experimental conditions and measurement were the same as in Figure 1. ( $n=6$ embryos from 3 different litters). Multiple 1-tailed Student's $t$ tests corrected for multiple comparisons using the Holm-Šídák method were used to compare each experimental condition; ${ }^{* *} P<0.005,{ }^{* * *} P<0.001$

origin of this disease. A recently published paper reported that cardiac familial hypertrophy displays an embryonic cardiac phenotype (36). Altogether, this suggests that genetic diseases often diagnosed at the adult stage feature an embryonic origin that has been overlooked and that may be used as a therapeutic preventive window.

In order to look for potential therapeutic targets, the molecular mechanism underlying the impairment of cardiac cell differentiation and function triggered by $L m n a^{\mathrm{H} 222 \mathrm{P} /+}$ mutation was investigated using mouse ESCs. A first observation from the qPCR data was that Mesp1, a mesendodermal gene marking cells within the cardiogenic mesoderm, was downregulated in mutant EBs. This pointed to a very early block in the process of cardiac differentiation. This block could be partially overcome with time because $L m n a^{\mathrm{H} 222 \mathrm{P} /+}$ cardiac cells within EBs start beating with a significant delay compared with WT EBs, although not to such an extent as WT cells. This indicates first that the phenotype in vitro is more severe than in vivo because some but not all $L m n a^{\mathrm{H} 222 \mathrm{P} /+}$ embryos develop normally up to birth. The more severe in vitro than in vivo phenotype has been previously observed (19). This might be attributed to compensatory mechanisms in the whole body that cannot occur in isolated cells.

Mespl is a key gene responsible for the EMT process of epiblast cells to allow them to migrate from the posterior to the anterior pole of E7.5 embryos $(21,22)$. Together with the observation that expression of both Twist and Snaill was slowed down in Lmna $a^{\mathrm{H} 222 \mathrm{P} /+}$ EBs, we reasoned that a defect in EMT was, in fact, a key event in the impairment of cardiac cell differentiation of ESCs and likely migration of mesodermal cardiogenic cells in the embryo. Interestingly, ChIP assays revealed that the H3K4me1 epigenetic mark was significantly lost on regulatory regions of EMT genes, including Mesp1 in Lmna ${ }^{\mathrm{H} 222 \mathrm{P} /+}$ EBs. Of note, Mesp1 is expressed in bipotent skeletal and cardiac progenitor cells $(37,38)$. A defect in Mesp1 expression as observed in p.H222P Lmna EBs could also play a role in skeletal muscle development and further in skeletal muscle dystrophy observed in patients with Emery-Dreifuss muscular dystrophy (39). Interestingly, Mesp1 expression has also been reported to be dysregulated in mesodermal differentiation of human induced pluripotent stem cells carrying a p.R482 mutation in the LMNA gene, a mutation responsible for lipodystrophy (40).

We did not check inhibition of Mesp1 in early E6.5-E7.5 lmn $a^{\text {H222P/ }}$ ${ }^{H 222 P}$ mouse embryos. Thus, our hypothesis relies on data obtained in EBs or human induced pluripotent stem cells, in vitro samples that may not fully recapitulate mouse or human development. However, 
A

Lmna

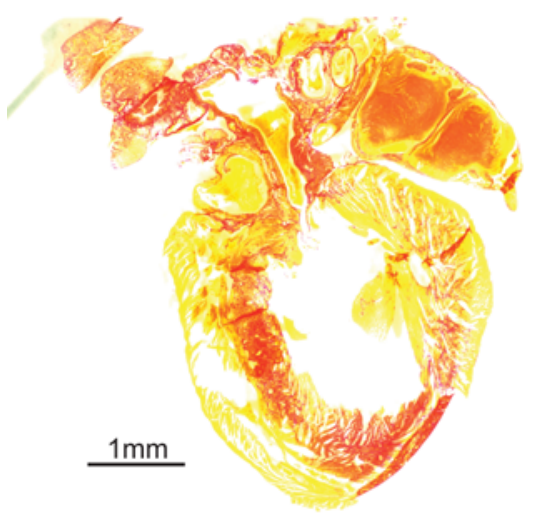

B

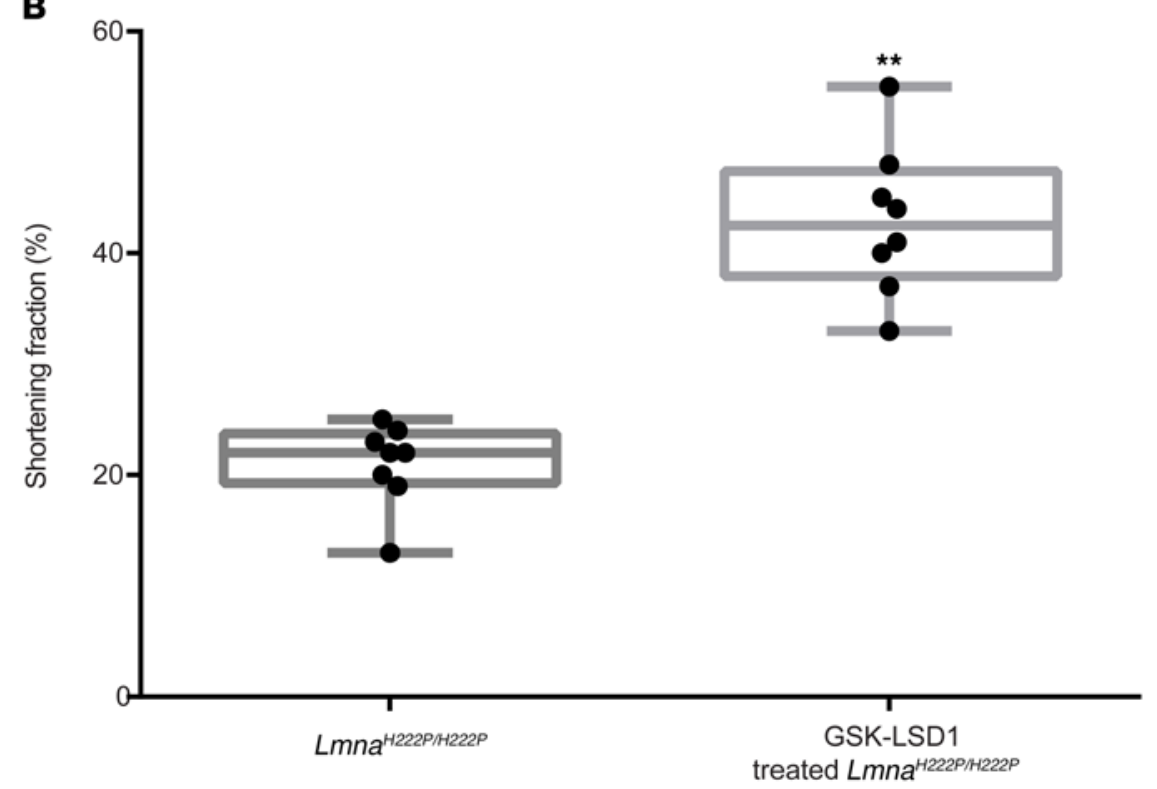

Figure 7. GSK-LSD1, the LSD1 inhibitor, prevents fibrosis and heart failure in Lmna ${ }^{\mathrm{H} 222 \mathrm{P} / \mathrm{H} 222 \mathrm{P}}$ mice. Lmna ${ }^{\text {H222P/H222P }}$ neonatal mice were treated with $1 \mathrm{mg} / \mathrm{kg}$ GSK-LSD1 at P0 and P3 by i.p. injection. The 8 nontreated and 8 treated mice were allowed to grow up to 6 months. Ultrasound echocardiography was then performed to evaluate their cardiac function before euthanasia. (A) The explanted hearts were processed in histology and heart sections stained with Sirius red. (B) Shortening fraction of left ventricle in nontreated $L m n a^{\mathrm{H} 222 \mathrm{P} / \mathrm{H} 222 \mathrm{P}}$ mice and in treated ones monitored by echocardiography. One-tailed Student's $t$ test; ${ }^{* *} P \leq 0.01$.

it is tempting to suggest that Mesp1 could thus be at the crossroad of transcriptional pathways dysregulated in many laminopathies.

LSD1 has been reported to be instrumental in regulating EMT (23). Interestingly, as observed in Lmna ${ }^{\mathrm{H} 222 \mathrm{P} /+} \mathrm{EBs}$, Brachyury is upregulated in the epiblast cells of LSD1-KO E6.5 (24) mice, suggesting that an appropriate dosage of LSD1 is mandatory for its context-dependent function within a specific chromatin complex (NurD, UTX, and/or co-REST) acting on specific loci and cell differentiation. Demethylase thus constituted a good candidate to explain the dysregulation of EMT genes and in turn cardiac defects in vitro and in vivo in p.H222P Lmna ESCs. We found that blunting LSD1 activity by a siRNA or a pharmacological inhibitor (GSKLSD1) could rescue the epigenetic H3K4me print of EMT genes and in turn expression of cardiac genes and cardiogenesis and cardiac function in vitro. In vivo inhibition of LSD1 in $L m n a^{\mathrm{H} 222 \mathrm{P} /+}$ pregnant females bred with $L m n a^{\mathrm{H} 222 \mathrm{P} /+}$ males also fully prevented cardiomyopathies in $L m n a^{\mathrm{H} 222 \mathrm{P} / \mathrm{H} 222 \mathrm{P}}$ embryos. Furthermore, and as a more relevant therapeutic window, in vivo inhibition of LSD1 in neonatal Lmna ${ }^{\mathrm{H} 222 \mathrm{P} / \mathrm{H} 222 \mathrm{P}}$ mice prevented their hearts from developing fibrosis, an EMT-mediated process (27), and dilatation, thus preventing heart failure.

Altogether, these data strongly suggest that p.H222P Lmna mutation leads to a hyperactivity of LSD1, not due to a change in enzymatic activity per se, but more likely after a sequestration of LSD1 and associated NurD, UTX, and/or co-REST complex (41) in a LAD, including Mesp1 and Twist, both genes located on chromosome 7 and 3 megabases distant from each other. We did not find any dysregulation of $\mathrm{H} 3 \mathrm{~K} 9 \mathrm{me} 2$ epigenetic marks on the Mesp1 or Twist promoter in Lmna ${ }^{\mathrm{H} 222 \mathrm{P} /+}$ EBs. Of note, we also observed an upregulation of LSD1 in p.H222P Lmna in day 4 EBs at the mesodermal stage of differentiation. The Lmna p.H222P mutation could also increase PRMT4 sequestration, which methylates arginines of both laminA/C (42) and LSD1, leading to its deubiquitination and in turn increasing its stability (43). This further points to the specificity of LSD1 action that targets methylated H3K4 or H3K9 depending upon the chromatin complex it is associated with $(44,45)$. LSD1 targeting EMT genes within the NurD and or UTX complex (46) thus acts as an inhibitor of EMT in embryonic stages. The p.H222P Lmna mutation could induce changes in 3D chromatin configuration, including the histone $\mathrm{H} 3$ that regulates LSD1/CoREST conformation (47).

GSK-LSD1 used to treat the female mice also prevented cardiomyopathy in the offspring. This further argues in favor of a congenital origin of the disease. Interestingly, however, there is a short postbirth window of time in which hearts submitted to an ischemic insult can be regenerated (28). The increased cardiac demand during birth likely serves as a trigger of a loss in cardiomyocytes and in turn development of fibrosis in Lmna $\mathrm{H} 222 \mathrm{P} / \mathrm{H} 222 \mathrm{P}$ hearts. LSD1 acts within the co-REST complex as a pro-EMT factor in cancer by erasing H3K4me1 and H3K9me2 epigenetic marks on E-cadherin genomic regulatory regions (48). We also found that in the postnatal stage, LSD1 led to a loss in H3K4me1 and $\mathrm{H} 3 \mathrm{~K} 9 \mathrm{me} 2$ marks on E-cadherin in lmna ${ }^{\mathrm{H} 222 \mathrm{P} / \mathrm{H} 222 \mathrm{P}}$ hearts, thus silencing the epithelial gene and promoting EMT of the cells. Targeting this window with GSK-LSD1 when $L m n a^{\mathrm{H} 222 \mathrm{P} / \mathrm{H} 222 \mathrm{P}}$ mice must increase their cardiac demand prevented heart failure at adulthood. This argues in favor of a key role of EMT in cardiac diseases and 
fibrosis, which is currently being debated $(26,27)$, and opens the path toward a therapeutic approach.

The H3K 4me1 epigenetic mark turns out to be crucial in the mesodermal cardiogenic transcriptional scenario. This epigenetic mark and in turn LSD1 that regulates histone modification is central in another genetic disease, DiGeorge syndrome (49). This points to H3K4me1 as an epigenetic mark at the crossroad of genomic pathways involved in key biological processes such as EMT. EMT during development and adult disease, which are both regulated by LSD1 and associated chromatin complexes, represents a druggable process that should be targeted to relieve severe symptoms of genetic cardiomyopathies. Interestingly, GSK-LSD1 is an on-market drug used in clinical trials in oncology. A repositioning of the drug for rare and cardiac diseases could be tested in individuals carrying the p. H222P LMNA mutation.

\section{Methods}

Mouse ESCs. CK35 WT, CGR8, and R1 ESCs, all from a 129 genetic strain background, were used as controls; Lmna $^{\mathrm{H} 222 \mathrm{P} /+}$ mutant cells were produced by homologous recombination in the CK35 WT cell line (50) after transfection of stable expression vector (16).

Propagation and differentiation. Mouse ESCs (CK35 WT and Lmna $^{\mathrm{H} 222 \mathrm{P} /+}$ mutant) were propagated on a feeder layer as previously described in a media containing recombinant leukemia inhibitory factor (1/1000 to $1 / 5000)$ (51). The cells were trypsinized and replated every 2 days. Differentiation was carried out using the hanging drop method (51). Cells were phenotyped every 10 passages using anti-OCT4 (Santa Cruz Biotechnology, SC9081) and NANOG (R\&D Systems, AF1997) (antibodies used at 1/100). Karyotype was found to be normal and stable in the course of the experiments.

$E B$ beating calculation. After 5 days of differentiation, EBs were plated individually on gelatin-coated 48 -well plates. The percentage of beating EBs was evaluated every day between days 7 and 18 to assess the differentiation efficiency.

\section{Mice}

$\mathrm{WT}, \operatorname{lm} n a^{\mathrm{H} 222 \mathrm{P}+/}$, and $l m n a^{\mathrm{H} 222 \mathrm{P} / \mathrm{H} 222 \mathrm{P}}$ mice were maintained in a 129S2/SvPasCrl genetic background with ad libitum food and water for 12-hour light/12-hour dark cycles. Besides embryos, only male adult mice (2-6 months old) were used in the study. The animal experiments were performed according to the guidelines from Directive 2010/63/EU of the European Parliament on the protection of animals used for scientific purposes.

\section{Ultrasound echocardiography}

Embryonic heart echocardiography was performed using a Vevo 2100 (FujiFilm VisualSonics) equipped with MS550 (40 MHz) or MS700 (50 $\mathrm{MHz}$ ) probes. Anesthesia of pregnant females was induced with $4 \%$ isoflurane and maintained using $1 \%-1.5 \%$ isoflurane. The abdomen was opened and the uterus exposed. Each embryo in the uterus was exposed through a hole in a plastic petri dish filled with warmed $\left(37^{\circ} \mathrm{C}\right)$ PBS during heart monitoring. Adult heart function was monitored using an Affiniti 50 (Philips) and an $11 \mathrm{MHz}$ probe. Mice were anaesthetized with $4 \%$ isoflurane and maintained under $1 \%-1.5 \%$ isoflurane. Echocardiographies were analyzed in a blinded manner by a cardiologist who had not performed the recordings.

Neonatal and adult mice were treated with $1 \mathrm{mg} / \mathrm{kg}$ of GSK-LSD1 (Sigma-Aldrich, SML-1072). GSK-LSD1 was administered by i.p. injection.

\section{LSD1 inhibition and assay}

ESCs were transfected with RNAi max (Thermo Fisher Scientific) added to LSD1 siRNA (100 nM, Santa Cruz Biotechnology) or treated with GSK LSD1 at $5 \mu \mathrm{M}$.

LSD1 activity was performed using the EpiQuick histone demethylase LSD1 Activity/Inhibition Assay Kit from Epigentek (P-3076-48).

Real-time quantitative PCR. Total RNAs were extracted from ESCs using a Zymo Research kit. One microgram of RNA was reverse transcribed using the SuperscriptII reverse transcriptase (Invitrogen) and oligo(16)dT. Quantitative PCR was performed using LightCycler LC480 (Roche). Amplification was carried out as recommended by the manufacturer. The $12 \mu \mathrm{L}$ reaction mixture contained $10 \mu \mathrm{L}$ of LightCycler-DNA Master SYBR Green I mix (FAST Start KIT, containing Taq DNA polymerase, reaction buffer, deoxynucleoside trisphosphate mix, and SYBR Green I dye), $3 \mathrm{mM} \mathrm{MgCl}$, $0.5 \mu \mathrm{M}$ concentration of appropriate primer, and $2 \mu \mathrm{L}$ of cDNA. The data were normalized by PCR analysis of ATP50 expression. Results were expressed as a function of the level of expression of the gene of interest in control undifferentiated stem cells using a previously described mathematical model (52). The amplification program included the initial denaturation step at $95^{\circ} \mathrm{C}$ for 8 minutes, and 40 cycles of denaturation at $95^{\circ} \mathrm{C}$ for 3 seconds, annealing at $65^{\circ} \mathrm{C}$ for 10 seconds, and extension at $72^{\circ} \mathrm{C}$ for 10 seconds. The temperature transition rate was $20^{\circ} \mathrm{C} / \mathrm{s}$. Fluorescence was measured at the end of each extension step. After amplification, a melting curve was acquired by heating the product at $20^{\circ} \mathrm{C} / \mathrm{s}$ to $95^{\circ} \mathrm{C}$, cooling it at $20^{\circ} \mathrm{C} / \mathrm{s}$ to $70^{\circ} \mathrm{C}$, keeping it at $70^{\circ} \mathrm{C}$ for 20 seconds, and then slowly heating it at $0.1^{\circ} \mathrm{C} / \mathrm{s}$ to $95^{\circ} \mathrm{C}$. Fluorescence was measured through the slow heating phase. Melting curves were used to determine the specificity of PCR products, which were confirmed using conventional gel electrophoresis. Primers used in this study are listed in Table 1.

RNA-Seq. Heterozygous p.H222P/ ${ }^{+}$and homozygous p.H222P/ H222P E13.5 embryos were collected from pregnant heterozygous p.H222P/ ${ }^{+}$females crossed with homozygous p.H222P/H222P males. Embryos were genotyped using the yolk sac. The hearts were dissected, and RNA was extracted using a Zymo Research kit. RNA was then used to generate a sequencing library or in real-time qPCR. RNA was sequenced using a NextSeq (Illumina). Sequence alignment using the mouse GRCm38/mm10 genome reached $94.91 \%$ and included $97.95 \%$ of intragenic regions. The data were analyzed using the DESeq2 application. Data are available in NCBI's Gene Expression Omnibus database (GEO GSE156975).

Western blotting. Protein extracts were separated by $10 \%$ SDSPAGE and transferred onto nitrocellulose membranes (Invitrogen). Blocking and antibody incubations were performed in 5\% BSA. Membranes were incubated with HRP-conjugated anti-mouse or anti-rabbit secondary antibodies (Jackson ImmunoResearch) for 1 hour at room temperature. Antibody detection reactions were developed by enhanced chemiluminescence (MilliporeSigma).

Immunofluorescence. ESCs or EBs were fixed in 3\% paraformaldehyde for 15 minutes at room temperature. After blocking in PBS-BSA 3\% 0.1\% Triton X-100 cells were incubated in PBS, $0.01 \%$ Triton X-100, 3\% BSA with the following: mouse anti-SSEA1 (Hybridoma Bank, University of Iowa, Iowa City, Iowa, USA, clone MC480), rabbit anti-Oct-3/4 antibody (Santa Cruz Biotechnology, catalog H134), mouse anti-sarcomeric $\alpha-$ actinin antibody (51) (1/500, Sigma-Aldrich, catalog H7811), anti-Nkx2.5 antibody (Santa Cruz Biotechnology, catalog H114), anti-Isl1 antibody 


\section{Table 1. Mouse gene primers used in this study}

\begin{tabular}{|c|c|c|}
\hline Gene name & Forward $\left(5^{\prime}-3^{\prime}\right)$ & Reverse $\left(5^{\prime}-3^{\prime}\right)$ \\
\hline ATP50 & ATGGGCAAGGTGAAGGTCGGAG & GATGATACGGTGGGTGTTGC \\
\hline Brachyury $(T)$ & САСTTCGTCACGССTCACAA & CGAGTCTGGGTGGATGTAG \\
\hline MesP1 & GTCСCTTTATCTGССТCTTCTG & AGCGGGGGTGTCTTGTCTC \\
\hline $\operatorname{Mef2c}$ & ACATACССАСААСАСАССАСССССС & ATCCTTCAGACAGTCGCATGCGCTT \\
\hline$|s| 1$ & CATCGAGTGTTTCCGCTGTGTAG & GTGGTCTTCTCCGGCTGCTTGTGG \\
\hline$N k \times 2.5$ & AСATTTTACCCGGGAGCCTACGGTC & GCTTTCCGTCGCCGCCGTGCGCGTG \\
\hline Tbx5 & CCAGCTCGGCGAAGGGATGTTT & СCGACGCCGTGTACCGAGTGAT \\
\hline Mxl1 & CAAGGCGGGGAGTTTTCCTC & TCCCAGGAGTCCAACTTTGAG \\
\hline Nestin & GAGAGAGGCGTGGAACAGAGATT & AGACATAGGTGGGATGGGAGTGCT \\
\hline GSC & САCATGCTGCССТACATGAAC & TCTGGGTACTTCGTCTCCTGG \\
\hline Sox17 & CGAGCCAAAGCGGAGTCTC & TGCСAAGGTCAACGСCTTC \\
\hline Nanog & TTGCCTCGTCTTGCTTTAGG & AAAATGAATGAACAAATGAAGAAAA \\
\hline Oct4 & TGCСTCCAAGTGTTGTCCC & ATTCATGTTGTCTTAGCTGCTTCC \\
\hline E-Cadherin & TCGACACCCGATTCAAAGTGG & TTCCAGAAACGGAGGCCTGAT \\
\hline Twist & GGAGTCCGCAGTCTTACGAG & TCTGGAGGACCTGGTAGAGG \\
\hline Snai1 & TATGCTGCCTTCCCAGGCTTG & ATGTGCATCTTGAGGGCACCC \\
\hline Fkl1 & GСATCTCATCTGTTACAGC & СТTCATCAATCTTTACСCC \\
\hline Pecam1 & GAGTCCTGCTCACССTTCTG & TCAGGTTCTTCCCATTTTGC \\
\hline Coosecoid & AGGTGGAGGTCTGGTTTAAGA & AGCTGTCCGAGTCCAAATCG \\
\hline Mix/1 & AGTTGCTGGAGCTCGTCTTC & AАTСACTTCССАСТCTGGCG \\
\hline FGF8 & GGGAAСССАССТGAСАСТСТС & TACGСAGTCСTTGCСTTTGC \\
\hline Mlc2a & TCTTCTAATGTCTTCTCAATGTTCG & ТСТАСТССТСТTTСТСАТССССGTG \\
\hline Mlc2v & GCCAAGAAGCGGATAGAAGG & CTGTGGTTCAGGGCTCAGTC \\
\hline BMP10 & САСТCСTGGATСATСGCTCСTC & CAAGGCCTCAATAATTGCGTGTT \\
\hline $\mathrm{Nppb}$ & GAGTCCTTCGGTCTCAAGGC & GCTGCAGGAGTATGCCAGAT \\
\hline Notch1 & GTGCCTGCCCTTTGAGTCTT & GCGATAGGAGCCGATCTCATTG \\
\hline Has2 & GAAAGGCAACCACAGCGAAG & ACATCAACCTACAAGCCGGG \\
\hline Nrg1 & TCAGCAAGTTAGGAAACGACAG & ACATAGGGTCTTTCAGTTCAGGC \\
\hline
\end{tabular}

(Hybridoma Bank, clone 39.3F7), anti-Mef2c antibody (Aviva Systems Biology, catalog ARP37342_T100), anti-LSD1 (Abcam, catalog ab17721), and anti- $\beta$ MHC antibody (Alexis Biochemicals, clone F109.3E1). Cells were then incubated with the appropriate secondary anti-rabbit or antimouse IgG coupled to Alexa Fluor 488 or Alexa Fluor 546 conjugated antibodies (Molecular Probes, Life Technologies, Thermo Fisher Scientific) diluted to $1 / 500$ in PBS, 0.1\% Tween 20,10\% donkey serum. Cells were incubated for 5 minutes in DAPI (Sigma-Aldrich) before mounting (Fluoromount-G, SouthernBiotech). Images were acquired using an apotome (Zeiss) and deconvoluted using AutoQuant software (Bitplane).

Intracellular calcium measurement. EBs were loaded with $50 \mu \mathrm{M}$ Fluo-A in cell culture medium from a $1 \mathrm{mg} / \mathrm{mL}$ stock in DMSO/20\% Pluronic acid Fluo4-AM (Thermo Fisher Scientific) for 15 minutes at $37^{\circ} \mathrm{C}$. $\mathrm{Ca}^{2+}$ transients at $37^{\circ} \mathrm{C}$ in DMEM, $10 \% \mathrm{FCS}$, and $10 \mathrm{mM}$ HEPES were measured with a Zeiss observer microscope equipped with a Hammatsu Camera $(2048 \times 2048$ pixels, 100 frames/s), using Zen-Pro software. Regions of interest were selected in cells within a beating area of EBs, and the average pixel intensity was plotted as a function of time. All experiments were performed at $35^{\circ} \mathrm{C} \pm 2^{\circ} \mathrm{C}$. The fluorescence signal was expressed as F-FO/FO, F0 being the lowest fluorescence signal recorded.

ChIP assay. ChIP was performed according to previously reported protocols (53). The ChIP-grade anti-H3K4me1 (c-15210018), anti-H3K27ac (c-15210016), and anti-H3K9me2 (c-15200154) antibodies were from Diagenode. qPCR primers for ChIP assays are listed in Table 2.
Table 2. ChIP primers in this study

\begin{tabular}{|c|c|c|}
\hline $\begin{array}{l}\text { Gene name } \\
\text { Regulatory regions }\end{array}$ & Forward $\left(5^{\prime}-3^{\prime}\right)$ & Reverse $\left(5^{\prime}-3^{\prime}\right)$ \\
\hline TwisT E2 & ATGTAAAGAGCCCTGCAATC & ACCTTCAAAССССAAAAAGG \\
\hline Mesp1E1 & GTCСCTCAAACTCACTCTCC & TGGCCTCTATCTACTACACAAGCA \\
\hline Mesp1E2 & TGAGACAGTCCAGTAGCATAGGA & САCGСACATGCCTGTAATTC \\
\hline Mesp1P & CGGGATGGTTTCTTCAATG & GGGACCTCTAGACACGGAGA \\
\hline E-CadherinP (A) & СATTCGAACGACСGTGGAATAG & СТGСАСGGСССТТСАСТT \\
\hline E-cadherin $P(B)$ & TCGGGAGACTCAAACAGCAG & GСTATTTCTCCGACGGTTTT \\
\hline E-cadherin E-2 (C) & GACCATTGACTCСCTTTCG & TGTGTATTGGTGTGAGGATGTC \\
\hline E-cadherin $E-3(D)$ & ACTTGCССAGTGCСATACAG & ССTCAGCGACAAACTGGATT \\
\hline E-cadherin $E+1$ (E) & AGGGACCGTAGATTGGGGTA & CACACGCCTTGACTCTT \\
\hline E-cadherin $E+2(F)$ & CAGGTTTTTGTTAATGTTGTTTCTTT & GGGGATCAACTAAAATCATGAGG \\
\hline
\end{tabular}

Embryonic and adult heart staining. Staining of heart sections was performed as previously described (54). Briefly, embryos or adult hearts were fixed overnight at $4^{\circ} \mathrm{C}$ with $4 \%$ paraformaldehyde, washed with PBS. The samples were dehydrated using ethanol 50\%, 70\%, and $100 \%$ and then xylene prior to paraffin embedding. The embryos were cut with a microtome. After rehydration, heart sections were stained with H\&E or Sirius red, or permeabilized with PBS 0.1\% Triton X-100 and blocked with PBS 0.1\% Tween 20 with $10 \%$ donkey serum; mouse anti-sarcomeric $\alpha$-actinin antibody (1/500, Sigma-Aldrich, catalog H7811), was added in PBS 10\% donkey serum and 0.1\% Tween 20. The secondary antibody Alexa Fluor 488 was added in PBS 0.1\% Tween 20.

Histopathological analysis of embryonic hearts was performed using ImageJ software (NIH).

\section{Statistics}

Results are presented as mean \pm SEM. The Student's $t$ test was used to analyze statistical significance. All $P$ values corresponded to a 2-tailed test, and a $P$ value less than 0.05 was considered statistically significant.

\section{Study approval}

The animal housing at INSERM U1251 at Marseille was approved by the Prefecture of Bouches du Rhône (Marseille) under agreement C13013-08. The PI Michel Puceat has animal experimentation authorization from the Ministry of Agriculture and Fisheries in France under the direction of animal health and protection (R-13 CNRS F1-10) for transgenic mice (Ministry of Higher Education, Research and Innovation agreement, OGM 2019-24 $\mathrm{N}^{\circ} 4435$ ).

\section{Author contributions}

ACG and IJ performed the majority of the experiments and analyzed data. ACG edited the manuscript. JL performed some ChIP experiments. EW performed the Western blots. NV helped in performing echocardiography of embryos and edited the manuscript. GB edited the manuscript. MP provided funding, designed experiments, supervised the students, analyzed data, and wrote the manuscript.

\section{Acknowledgments}

We thank Hany J. Neametalla (George Pompidou European Hospital, Paris) and Virginie Lambert (Institut Mutualiste Montsouris, Paris) for expert assistance in echocardiography and C. Enond 
and her team at the animal facility of Pitié-Salpêtrière campus (SU-Inserm UMS28, Phenotypage du petit animal), Denis Arnaud for technical assistance, the Ministère de la Recherche et de Ministered la Technologie for an ACG fellowship, the French National Research Agency program Genopath (to MP) for supporting the major part of this research, and Association Institut of Myology for supporting part of this research (to NV and GB), and the SATT (Société d'Accélération du Transfert de Technologies) Sud Est for support of this research (to MP). We thank the Leducq Fondation for generously awarding funds for our cell imaging facility ("Equipement de Recherche et Plateformes Technologiques" to MP).
Address correspondence to: Michel Pucéat, INSERM UMR 1251, MMG, Faculté de Médecine La Timone, 27 bd Jean moulin, Marseille, 13885, France. Phone: 33.491324942; Email: michel.puceat@inserm.fr. ACG’s present address is: bit bio ltd, Cambridge Biomedical Campus, Cambridge CB2 OAX United Kingdom. IJ's present address is: Sorbonne University, Faculté de Médecine, ICAN, Institute of Cardiometabolism And Nutrition, INSERM UMR_S1166, Paris, France. JL's present address is: Institute of Physiological Chemistry, University Medical Center, Johannes Gutenberg University Mainz Duesbergweg 6 55128 Mainz, Germany.
1. Solovei I, et al. LBR and lamin A/C sequentially tether peripheral heterochromatin and inversely regulate differentiation. Cell. 2013;152(3):584-598.

2. van Steensel B, Belmont AS. Lamina-associated domains: links with chromosome architecture, Heterochromatin, and Gene Repression. Cell. 2017;169(5):780-791.

3. Gesson K, Rescheneder P, Skoruppa MP, von Haeseler A, Dechat T, Foisner R. A-type lamins bind both hetero- and euchromatin, the latter being regulated by lamina-associated polypeptide 2 alpha. Genome Res. 2016;26(4):462-473.

4. Gruenbaum Y, Foisner R. Lamins: nuclear intermediate filament proteins with fundamental functions in nuclear mechanics and genome regulation. Annu Rev Biochem. 2015;84:131-164.

5. Dittmer TA, Misteli T. The lamin protein family. Genome Biol. 2011;12(5):222.

6. Cattin ME, Muchir A, Bonne G. 'State-of-theheart' of cardiac laminopathies. Curr Opin Cardiol. 2013;28(3):297-304.

7. Cho S, Irianto J, Discher DE. Mechanosensing by the nucleus: from pathways to scaling relationships. J Cell Biol. 2017;216(2):305-315.

8. Cesarini E, et al. Lamin A/C sustains PcG protein architecture, maintaining transcriptional repression at target genes. J Cell Biol. 2015;211(3):533-551.

9. Salvarani N, et al. The K219T-Lamin mutation induces conduction defects through epigenetic inhibition of SCN5A in human cardiac laminopathy. Nature communications. 2019;10(1):2267.

10. Bianchi A, et al. Dysfunctional polycomb transcriptional repression contributes to lamin A/C-dependent muscular dystrophy. J Clin Invest. 2020;130(5):2408-2421.

11. Bonn S, et al. Tissue-specific analysis of chromatin state identifies temporal signatures of enhancer activity during embryonic development. Nat Genet. 2012;44(2):148-156.

12. Peric-Hupkes D, van Steensel B. Role of the nuclear lamina in genome organization and gene expression. Cold Spring Harb Symp Quant Biol. 2010;75:517-524.

13. Perovanovic J, et al. Laminopathies disrupt epigenomic developmental programs and cell fate. Science translational medicine. 2016;8(335):335ra58.

14. Van Vliet P, Wu SM, Zaffran S, Pucéat M. Early cardiac development: a view from stem cells to embryos. Cardiovasc Res. 2012;96(3):352-362.

15. Eckersley-Maslin MA, Bergmann JH, Lazar Z, Spector DL. Lamin A/C is expressed in plurip- otent mouse embryonic stem cells. Nucleus. 2013;4(1):53-60.

16. Arimura T, et al. Mouse model carrying H222P-Lmna mutation develops muscular dystrophy and dilated cardiomyopathy similar to human striated muscle laminopathies. Hum Mol Genet. 2005;14(1):155-169.

17. Vignier N, Mougenot N, Bonne G, Muchir A. Effect of genetic background on the cardiac phenotype in a mouse model of Emery-Dreifuss muscular dystrophy. Biochem Biophys Rep. 2019;19:100664.

18. Houliston E, Guilly MN, Courvalin JC, Maro B. Expression of nuclear lamins during mouse preimplantation development. Development. 1988;102(2):271-278.

19. Grey C, Méry A, Pucéat M. Fine-tuning in Ca2+ homeostasis underlies progression of cardiomyopathy in myocytes derived from genetically modified embryonic stem cells. Hum Mol Genet. 2005;14(10):1367-1377.

20. Maltsev VA, Wobus AM, Rohwedel J, Bader M, Hescheler J. Cardiomyocytes differentiated in vitro from embryonic stem cells developmentally express cardiac-specific genes and ionic currents. Circ Res. 1994;75(2):233-244.

21. Lindsley RC, et al. Mesp1 coordinately regulates cardiovascular fate restriction and epithelial-mesenchymal transition in differentiating ESCs. Cell Stem Cell. 2008;3(1):55-68.

22. Kitajima S, Takagi A, Inoue T, Saga Y. MesP1 and MesP2 are essential for the development of cardiac mesoderm. Development. 2000;127(15):3215-3226.

23. McDonald OG, Wu H, Timp W, Doi A, Feinberg AP. Genome-scale epigenetic reprogramming during epithelial-to-mesenchymal transition. Nat Struct Mol Biol. 2011;18(8):867-874.

24. Foster CT, et al. Lysine-specific demethylase 1 regulates the embryonic transcriptome and CoREST stability. Mol Cell Biol. 2010;30(20):4851-4863.

25. Krishnan A, et al. A detailed comparison of mouse and human cardiac development. Pediatr Res. 2014;76(6):500-507.

26. Li Y, Lui KO, Zhou B. Reassessing endothelial-to-mesenchymal transition in cardiovascular diseases. Nat Rev Cardiol. 2018;15(8):445-456.

27. Kovacic JC, et al. Endothelial to mesenchymal transition in cardiovascular disease: JACC State-of-the-Art Review. J Am Coll Cardiol. 2019;73(2):190-209.

28. Porrello ER, et al. Transient regenerative potential of the neonatal mouse heart. Science. 2011;331(6020):1078-1080.
29. Hasselberg NE, et al. Lamin A/C cardiomyopathy: young onset, high penetrance, and frequent need for heart transplantation. Eur Heart J. 2018;39(10):853-860.

30. Bonne G, et al. Clinical and molecular genetic spectrum of autosomal dominant Emery-Dreifuss muscular dystrophy due to mutations of the lamin A/C gene. Ann Neurol. 2000;48(2):170-180.

31. Grego-Bessa J, et al. Notch signaling is essential for ventricular chamber development. Dev Cell. 2007;12(3):415-429.

32. Mulligan P, et al. A SIRT1-LSD1 corepressor complex regulates Notch target gene expression and development. Mol Cell. 2011;42(5):689-699.

33. Yatim A, et al. NOTCH1 nuclear interactome reveals key regulators of its transcriptional activity and oncogenic function. Mol Cell. 2012;48(3):445-458.

34. Long PA, Evans JM, Olson TM. Diagnostic yield of whole exome sequencing in pediatric dilated cardiomyopathy. JCardiovasc Dev Dis. 2017;4(3):11.

35. Ben Yaou R,et al. First results from the international LMNA-related congenital and childhood onset muscular dystrophy retrospective natural history study. Neuromuscul Disord. 2017;27(suppl 2):S137-S138.

36. Mearini G, et al. Mybpc3 gene therapy for neonatal cardiomyopathy enables long-term disease prevention in mice. Nat Commun. 2014;5:5515

37. Chan SS, et al. Mesp1 patterns mesoderm into cardiac, hematopoietic, or skeletal myogenic progenitors in a context-dependent manner. Cell Stem Cell. 2013;12(5):587-601.

38. Chan SS, et al. Development of bipotent cardiac/ skeletal myogenic progenitors from MESP1+ mesoderm. Stem Cell Reports. 2016;6(1):26-34.

39. Penaloza JS, Pappas MP, Hagen HR, Xie N, Chan SSK. Single-cell RNA-seq analysis of Mesp1induced skeletal myogenic development. Biochem Biophys Res Commun. 2019;520(2):284-290.

40. Briand N, et al. The lipodystrophic hotspot lamin A p.R482W mutation deregulates the mesodermal inducer T/Brachyury and early vascular differentiation gene networks. Hum Mol Genet. 2018;27(8):1447-1459.

41. Shi YJ, Matson C, Lan F, Iwase S, Baba T, Shi Y. Regulation of LSD1 histone demethylase activity by its associated factors. Mol Cell. 2005;19(6):857-864.

42. Kim SJ, Yoo BC, Uhm CS, Lee SW. Posttranslational arginine methylation of lamin A/C during myoblast fusion. Biochim Biophys Acta. 
2011;1814(2):308-317.

43. Liu J, et al. Arginine methylation-dependent LSD1 stability promotes invasion and metastasis of breast cancer. EMBO Rep. 2020;21(2):e48597.

44. Garcia-Bassets I, et al. Histone methylationdependent mechanisms impose ligand dependency for gene activation by nuclear receptors. Cell. 2007;128(3):505-518.

45. Wissmann M, et al. Cooperative demethylation by JMJD2C and LSD1 promotes androgen receptor-dependent gene expression. Nat Cell Biol. 2007;9(3):347-353.

46. Choi HJ, et al. UTX inhibits EMT-induced breast CSC properties by epigenetic repression of EMT genes in cooperation with LSD1 and HDAC1. EMBO Rep. 2015;16(10):1288-1298.
47. Baron R, Vellore NA. LSD1/CoREST is an allosteric nanoscale clamp regulated by $\mathrm{H} 3$-histone-tail molecular recognition. Proc Natl Acad Sci U S A. 2012;109(31):12509-12514.

48. Ambrosio S, Saccà CD, Majello B. Epigenetic regulation of epithelial to mesenchymal transition by the Lysine-specific demethylase LSD1/ KDM1A. Biochim Biophys Acta Gene Regul Mech. 2017;1860(9):905-910.

49. Fulcoli FG, Franzese M, Liu X, Zhang Z, Angelini C, Baldini A. Rebalancing gene haploinsufficiency in vivo by targeting chromatin. Nat Commun. 2016;7:11688.

50. Kress C, Vandormael-Pournin S, Baldacci P, Cohen-Tannoudji M, Babinet C. Nonpermissiveness for mouse embryonic stem (ES) cell derivation circumvented by a single backcross to 129 /
Sv strain: establishment of ES cell lines bearing the Omd conditional lethal mutation. Mamm Genome. 1998;9(12):998-1001.

51. Meyer N, Jaconi M, Landopoulou A, Fort P, Pucéat $M$. A fluorescent reporter gene as a marker for ventricular specification in ES-derived cardiac cells. FEBS Lett. 2000;478(1-2):151-158.

52. Pfaffl MW. A new mathematical model for relative quantification in real-time RT-PCR. Nucleic Acids Res. 2001;29(9):e45.

53. Jebeniani I, Leschik J, Puceat M. Epigenetic regulation of cardiac differentiation of embryonic stem cells and tissues. JVis Exp. 2016(112): e53874.

54. Rouleau M, et al. TAp63 is important for cardiac differentiation of embryonic stem cells and heart development. Stem Cells. 2011;29(11):1672-1683. 